\title{
Sugarcane genes associated with sucrose content
} Flávia S Papini-Terzi ${ }^{1}$, Flávia R Rocha ${ }^{1}$, Ricardo ZN Vêncio², Juliana M Felix ${ }^{3,5}$, Diana S Branco ${ }^{3}$, Alessandro J Waclawovsky ${ }^{1}$, Luiz EV Del Bem $^{3}$, Carolina G Lembke ${ }^{1}$, Maximiller DL Costa ${ }^{1}$, Milton Y Nishiyama Jr${ }^{1}$, Renato Vicentini ${ }^{4,5}$, Michel GA Vincentz ${ }^{3,4}$, Eugênio C Ulian ${ }^{5,6}$, Marcelo Menossi ${ }^{4}$ and Glaucia M Souza*1

Address: ${ }^{1}$ Departamento de Bioquímica, Instituto de Química, Universidade de São Paulo, São Paulo, SP, Brazil, ${ }^{2}$ BIOINFO-USP Núcleo de Pesquisas em Bioinformática, Universidade de São Paulo, São Paulo, SP, Brazil, ${ }^{3}$ Centro de Biologia Molecular e Engenharia Genética, Universidade Estadual de Campinas, Campinas, SP, Brazil, ${ }^{4}$ Departamento de Genética e Evolução, Instituto de Biologia, Universidade Estadual de Campinas, Campinas, SP, Brazil, ${ }^{5}$ Centro de Tecnologia Canavieira, Piracicaba, São Paulo, SP, Brazil and ${ }^{6}$ Monsanto do Brasil Ltda, São Paulo, SP, Brazil

Email: Flávia S Papini-Terzi - flastal@yahoo.com.br; Flávia R Rocha - flavia.r.rocha@gmail.com; Ricardo ZN Vêncio - rvencio@gmail.com; Juliana M Felix - felix@ctc.com.br; Diana S Branco - dianabranco@gmail.com; Alessandro J Waclawovsky - ajw.bio@gmail.com; Luiz EV Del Bem - dudelben@gmail.com; Carolina G Lembke - carolina.lembke@gmail.com; Maximiller DL Costa - maximiller@gmail.com; Milton Y Nishiyama - yutakajr@iq.usp.br; Renato Vicentini - rvicentini@ctc.com.br; Michel GA Vincentz - mgavince@unicamp.br; Eugênio C Ulian - eugenio.ulian@gmail.com; Marcelo Menossi - menossi@unicamp.br; Glaucia M Souza* - glmsouza@iq.usp.br * Corresponding author

Published: 21 March 2009

BMC Genomics 2009, 10:120 doi:10.1186/147|-2164-10-120
Received: | 4 November 2008

Accepted: 21 March 2009

This article is available from: http://www.biomedcentral.com/I47/-2/64/I0//20

(c) 2009 Papini-Terzi et al; licensee BioMed Central Ltd.

This is an Open Access article distributed under the terms of the Creative Commons Attribution License (http://creativecommons.org/licenses/by/2.0), which permits unrestricted use, distribution, and reproduction in any medium, provided the original work is properly cited.

\begin{abstract}
Background -: Sucrose content is a highly desirable trait in sugarcane as the worldwide demand for cost-effective biofuels surges. Sugarcane cultivars differ in their capacity to accumulate sucrose and breeding programs routinely perform crosses to identify genotypes able to produce more sucrose. Sucrose content in the mature internodes reach around $20 \%$ of the culms dry weight. Genotypes in the populations reflect their genetic program and may display contrasting growth, development, and physiology, all of which affect carbohydrate metabolism. Few studies have profiled gene expression related to sugarcane's sugar content. The identification of signal transduction components and transcription factors that might regulate sugar accumulation is highly desirable if we are to improve this characteristic of sugarcane plants.
\end{abstract}

Results -: We have evaluated thirty genotypes that have different Brix (sugar) levels and identified genes differentially expressed in internodes using cDNA microarrays. These genes were compared to existing gene expression data for sugarcane plants subjected to diverse stress and hormone treatments. The comparisons revealed a strong overlap between the drought and sucrose-content datasets and a limited overlap with $A B A$ signaling. Genes associated with sucrose content were extensively validated by $\mathrm{qRT}-\mathrm{PCR}$, which highlighted several protein kinases and transcription factors that are likely to be regulators of sucrose accumulation. The data also indicate that aquaporins, as well as lignin biosynthesis and cell wall metabolism genes, are strongly related to sucrose accumulation. Moreover, sucrose-associated genes were shown to be directly responsive to short term sucrose stimuli, confirming their role in sugar-related pathways.

Conclusion -: Gene expression analysis of sugarcane populations contrasting for sucrose content indicated a possible overlap with drought and cell wall metabolism processes and suggested signaling and transcriptional regulators to be used as molecular markers in breeding programs. Transgenic research is necessary to further clarify the role of the genes and define targets useful for sugarcane improvement programs based on transgenic plants. 


\section{Background}

The importance of bioenergy-generating crops such as sugarcane is increasing rapidly and is likely to play an increasing role given the environmental and economical challenges of fossil fuel usage. Sugarcane belongs to the Saccharum L. genus, which derives from crosses of the domesticated species $S$. officinarum (a group that has sweet canes with thick and juicy culms), natural hybrids (S. sinense and S. barberi) and S. spontaneum (a wild species with no sugar and thin culms). All modern cultivars are derived from a few intercrossings of these hybrids [1-5]. Sucrose content is a phenotypic characteristic selected over centuries by breeding programs. Sugarcane cultivars differ in both maximum sucrose accumulation capacity and accumulation dynamics during growth [6]. Breeding programs routinely perform crosses to identify genotypes able to produce more sucrose early in the crop season to allow for continuous sugar production throughout the year. The internodes mature progressively towards the base of the culms with an increasing concentration of sucrose at the base. Sucrose content in the mature internodes can reach around $20 \%$ of the culms dry weight while lower sucrose levels are observed in younger internodes where glucose and fructose are predominant.

The improvement of modern cultivars could be achieved by identifying genes associated with important agronomic traits, such as sucrose content. These genes can then be used to generate transgenic plants or can serve as molecular markers for map-assisted breeding [7]. Internodes have been expression-profiled during culm development [812], but differences between cultivars that contrast for sucrose content have not been extensively reported. Understanding differences in the regulation of genes related directly or indirectly to sucrose accumulation in different cultivars is an important step if we want to aid breeding for sugar yield improvement. It is also important to understand the impact of environmental stresses on sucrose accumulation and the role of hormones in integrating stress signaling and developmental cues. Water stress, for example, reduces yield drastically and therefore, drought-tolerant sugarcane cultivars might be critically important in a scenario of cultivation expansion since much of the land available for sugarcane cultivation is located in regions subjected to drought. Drought responses include immediate protective measures and long term growth alterations [13]. Modulation of gene expression under this stress [14-19] involves ABA-dependent and independent pathways [13]. Carbohydrate metabolism is also related to abiotic stress responses since some aspects of the regulation of sugar metabolism are mediated by ABA and fructose, raffinose and trehalose act as osmoprotectants [20]. It is important to emphasize that some sugars (such as glucose, trehalose and sucrose) are important signaling molecules that affect plant growth and development including germination, early vegetative growth and flowering, as well as a variety of physiological processes such as photosynthesis, resource partition and defense responses [21-26]. The pathways activated by sugars cross-talk with other pathways, including those related to hormonal, cell cycle control and nitrogen responses [27-30]. ABA and sucrose were shown to be involved in the control of sucrose levels in plant cells [21] but the underlying mechanisms are still unknown.

We previously used cDNA microarrays to identify sugarcane genes that are responsive to drought and ABA [31]. The cDNAs are derived from a collection of 237,954 ESTs developed by the SUCEST sugarcane EST project [32] which were assembled into 43,141 putative, unique sugarcane transcripts that are referred to as Sugarcane Assembled Sequences (SAS). In this report we present the results of a large-scale analysis of the transcriptome of thirty genotypes grown in the field. cDNA microarrays were used to compare high- and low-Brix individuals and a comparison was made to reveal gene expression patterns that correlate with sucrose content, culm development, sugar treatments, drought and ABA treatment. We performed an extensive validation of cDNA microarray data using pooled plants, as well as individual genotypes. The results indicate a close relationship between sucrose content and drought signaling.

\section{Results}

cDNA microarrays were used to identify genes that were differentially expressed in genotypes contrasting for sucrose content. The arrays preparation, validation and analysis were done as previously described [31]. Multiple crossings were performed for twelve years among $S$. officinarum and $S$. spontaneum (Population 1) and between commercial varieties SP80-180 and SP80-4966 (Population 2) to generate genotypes with extreme values of sugar content. The simplest way to access phenotypic differences with a high degree of confidence is to measure sucrose in the culm juice. This can be done in the field using a simple refractometer that evaluates Brix (soluble solids content). In sugarcane most of the soluble solids in the juice (70 to $91 \%$ ) correspond to sucrose. Using this approach, thousands of genotypes can be phenotyped and contrasting individuals among the populations can be selected for further agronomic evaluation. Brix measurements were taken from 500 individuals of each population and the extreme clones in this population were selected and evaluated for sucrose content (see Additional file 1). To evaluate gene expression samples were collected from single individuals as well as from pools of seven or eight plants grown for seven, ten and elevenmonths.

Two experimental designs were used to perform transcriptome comparisons: (I), internodes 1, 5 and 9 from high 
Brix plants were compared to the same internodes from low Brix plants (HB vs LB) in both populations or (II), mature internodes 9 were compared to immature internodes 1 from plants with high or low Brix in population 2 [33]. Twenty six hybridizations were performed revealing 239 genes associated with sucrose content and regulated during culm development (see Additional file 2 and Figure 1).

A total of 117 genes were found to be differentially expressed in at least one comparison between high and low Brix genotypes (internodes 1, 5 or 9), and ten genes (SCCCLR1048F03.g, SCCCLR2003E10.g, SCCCRZ1001 F02.g, SCCCRZ1001H05.g, SCCCRZ1002E08.g, SCEZS T3147A10.g, SCJFRZ2007F10.g, SCAGLR1043E04.g, SCS BHR1050B11.g and SCVPCL6041F01.g) were found to be differentially expressed in both populations analyzed (see Additional file 2). Among these SAS, we found three transcription factors, two aquaporins and two transcripts

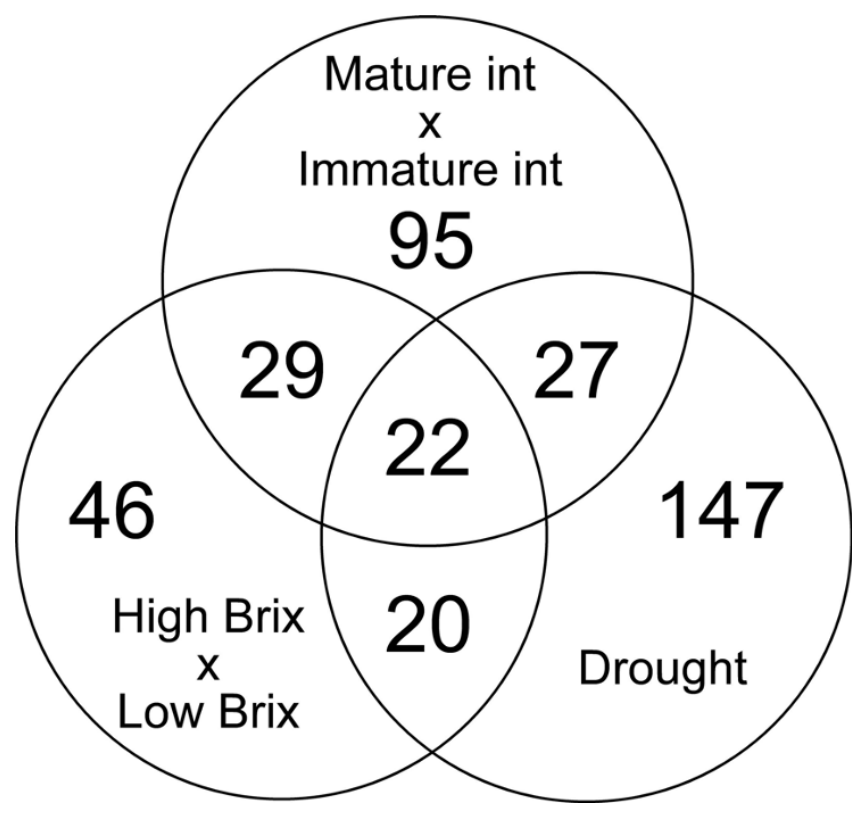

Figure I

Comparison of differential gene expression associated with sucrose content, culm development and drought responses in sugarcane. Genes were identified as associated with sucrose content if they were differentially expressed when high Brix or low Brix pools of plants were compared. Genes regulated during culm development were identified by comparing Mature and Immature Internodes. The drought-responsive genes were found to be induced or repressed by drought after 24,72 or $120 \mathrm{~h}$ of water deficit. The figure represents a Venn diagram of the three differential expression data sets. Technical replicates range from 2 to 16 since genes are spotted several times in the same array. The credibility level used to define outliers was 0.96 in all three data sets. related to development. The gene expression comparison between mature and immature internodes showed a total of 173 differentially expressed genes (see Additional file 2 and Figure 1).

Table 1 lists a selection of the differentially expressed genes along with the number of biological samples that displayed altered expression when high and low Brix pools of plants were compared (HB vs LB) and when mature and immature internodes were compared (MI vs II). The expression data sets were compared to those obtained for plants exposed to drought conditions or ABA treatment [31] (see Additional file 2). Comparison to ABA treated plants yielded eleven differentially expressed genes in common, including the ScPKABA1-3 (SCRFL R1034G06.g) and the ScMAPK-4 (SCSBAM1084E01.g), which were both more expressed in high Brix and repressed by ABA, and a PP2C-like protein phosphatase (SCEPRZ1010E06.g) which showed the opposite profile. Comparison to drought-regulated genes showed an extensive overlap in differential expression between the two datasets. Between 117 and 173 genes associated with high sucrose content and internode development, respectively, $43.6 \%$ and $28.3 \%$ were previously shown to be altered by drought while twenty-two genes were altered in all conditions analyzed (Figure 1).

Expression data of forty-two genes was also obtained using qRT-PCR. We determined gene expression differences for pools of extreme individuals from both populations (Figure 2), in mature and immature internodes (Figure 3 ) and in response to drought and ABA treatment (Figure 4). The significance of the data obtained by qRTPCR was inferred statistically by calculating values of P for expression differences against the reference sample (see Methods for details). Overall gene expression data obtained using cDNA microarrays was confirmed in qRTPCR experiments for over $80 \%$ of the genes tested, even when the target RNA derived from a distinct biological replicate. We also investigated, using qRT-PCR, how the expression levels varied among the individual genotypes from Population 1 (Figure 5). In this case, the value of $P$ was calculated against the average expression level across genotypes and the validation rate was around $58 \%$. Additional file 3 lists all the values of $P$ for the validated genes.

In order to unravel signaling aspects of sucrose accumulation, we asked whether genes differentially expressed in contrasting Brix genotypes or in mature-versus-immature internodes could represent direct sucrose- and/or glucoseregulated genes and, therefore, be part of the sucrose- and glucose-response pathways. To this end, sugarcane seedlings were treated with $3 \%$ sucrose or $3 \%$ glucose for $4 \mathrm{~h}$ and the expression of thirty-four genes was analyzed by qRT-PCR. The expression of thirty of these genes was 
Table I: Selection of SAS showing differential expression when high and low Brix plants were compared or when mature and immature internodes were compared.

\begin{tabular}{|c|c|c|c|c|c|c|c|c|c|}
\hline SAS & category & sub category I & sub category 2 & HB vs LB & MI vs II & Drought & ABA & Suc & Gluc \\
\hline SCCCLRI022D05.g & adapter & 14-3-3 protein & GFI4 & & $\downarrow$ & & & & \\
\hline SCCCRZI00ID02.g & adapter & 14-3-3 protein & GFI4 & & $\downarrow \downarrow \downarrow \downarrow$ & & & & \\
\hline SCEQRTI03ID02.g & adapter & 14-3-3 protein & GFI4 & & $\downarrow \downarrow$ & & & & \\
\hline SCEQRTI025D06.g & adapter & 14-3-3 protein & GFI4 & & $\downarrow$ & $\downarrow \downarrow$ & & & \\
\hline SCVPLRI049C09.g & $\begin{array}{l}\text { calcium } \\
\text { metabolism }\end{array}$ & $\begin{array}{l}\text { calmodulin-binding } \\
\text { protein }\end{array}$ & $\begin{array}{l}\text { AAA family ATPase } \\
\text { (cell division cycle } \\
\text { protein } 48 \text { sub- } \\
\text { family) }\end{array}$ & & $\downarrow$ & & & & \\
\hline SCCCRZICOIH06.g & $\begin{array}{l}\text { calcium } \\
\text { metabolism }\end{array}$ & $\begin{array}{l}\text { calmodulin-binding } \\
\text { protein }\end{array}$ & $\begin{array}{l}\text { Apyrase } \\
\text { (Nucleoside } \\
\text { diphosphatase) }\end{array}$ & & $\downarrow \downarrow \downarrow \downarrow$ & $\downarrow \downarrow$ & & & \\
\hline SCJLLRI I 08H07.g & $\begin{array}{l}\text { calcium } \\
\text { metabolism }\end{array}$ & $\begin{array}{l}\text { calmodulin-binding } \\
\text { protein }\end{array}$ & $\mathrm{Ca}(2+)$-ATPase & & $\downarrow$ & & & & \\
\hline SCEZLBIOI2FI0.g & $\begin{array}{l}\text { calcium } \\
\text { metabolism }\end{array}$ & $\begin{array}{l}\text { calmodulin-binding } \\
\text { protein }\end{array}$ & $\begin{array}{l}\text { Cyclic nucleotide- } \\
\text { gated calmodulin- } \\
\text { binding ion channel }\end{array}$ & $\uparrow$ & & & & & \\
\hline SCCCAMI00IA03.g & $\begin{array}{l}\text { calcium } \\
\text { metabolism }\end{array}$ & $\begin{array}{l}\text { calmodulin-binding } \\
\text { protein }\end{array}$ & $\begin{array}{l}\text { Multidrug resistant } \\
\text { (MDR) ABC } \\
\text { transporter }\end{array}$ & $\uparrow$ & & & & $\uparrow \uparrow$ & \\
\hline SCRFLR2037F09.g & $\begin{array}{l}\text { calcium } \\
\text { metabolism }\end{array}$ & calreticulin & CRT2 Calreticulin 2 & $\downarrow$ & $\downarrow \downarrow$ & $\uparrow \uparrow$ & & $\uparrow \uparrow \uparrow$ & $\uparrow \uparrow \uparrow$ \\
\hline SCCCLR2C02A05.g & $\begin{array}{l}\text { cell wall } \\
\text { metabolism }\end{array}$ & expansin & EXPAII & $\downarrow$ & $\downarrow \downarrow$ & & & & \\
\hline SCQGRTI040G03.g & $\begin{array}{l}\text { cell wall } \\
\text { metabolism }\end{array}$ & expansin & OsEXPA23 & $\uparrow$ & & $\downarrow \downarrow$ & & & \\
\hline SCACSBI037A07.g & $\begin{array}{l}\text { cell wall } \\
\text { metabolism }\end{array}$ & cytochrome P450 & $\begin{array}{l}\text { P-coumaroyl } \\
\text { shikimate } 3^{\prime}- \\
\text { hydroxylase }\end{array}$ & $\downarrow \downarrow$ & & & & & \\
\hline SCEZHRI087F06.g & $\begin{array}{l}\text { cell wall } \\
\text { metabolism }\end{array}$ & cytochrome P450 & $\begin{array}{l}\text { Ferulate-5- } \\
\text { hydroxylase }\end{array}$ & $\downarrow$ & $\uparrow \uparrow$ & & & & \\
\hline SCSGFL4I93B05.g & $\begin{array}{l}\text { cell wall } \\
\text { metabolism }\end{array}$ & cytochrome P450 & $\begin{array}{l}\text { Cinnamic acid 4- } \\
\text { hydroxylase }\end{array}$ & $\downarrow$ & & & & & \\
\hline SCRFLRIOI2FI2.g & $\begin{array}{l}\text { cell wall } \\
\text { metabolism }\end{array}$ & . & $\begin{array}{l}\text { Caffeic acid 3-O- } \\
\text { methyltransferase }\end{array}$ & $\uparrow \uparrow$ & $\uparrow \uparrow$ & & & & \\
\hline SCBFLRI039B05.g & $\begin{array}{l}\text { cell wall } \\
\text { metabolism }\end{array}$ & $\begin{array}{l}\text { polysaccharide } \\
\text { metabolism }\end{array}$ & $\begin{array}{l}\text { Xyloglucan } \\
\text { endotransglycosylase }\end{array}$ & & $\downarrow \downarrow \downarrow \downarrow$ & & & & \\
\hline SCCCLRI048D07.g & $\begin{array}{l}\text { cell wall } \\
\text { metabolism }\end{array}$ & lignin & $\begin{array}{l}\text { Phenylalanine } \\
\text { ammonia-lyase }\end{array}$ & $\uparrow$ & & $\downarrow \downarrow$ & & & \\
\hline SCEQRTI024EI2.g & $\begin{array}{l}\text { cell wall } \\
\text { metabolism }\end{array}$ & lignin & $\begin{array}{l}\text { Phenylalanine } \\
\text { ammonia-lyase }\end{array}$ & $\uparrow$ & $\downarrow$ & $\downarrow \downarrow$ & $\uparrow \uparrow$ & $\uparrow \uparrow \uparrow$ & $\uparrow \uparrow \uparrow$ \\
\hline SCSGAMI094D05.g & $\begin{array}{l}\text { cell wall } \\
\text { metabolism }\end{array}$ & lignin & $\begin{array}{l}\text { Phenylalanine } \\
\text { ammonia-lyase }\end{array}$ & $\downarrow$ & $\downarrow$ & & & & \\
\hline SCCCCL6002B05.g & $\begin{array}{l}\text { hormone } \\
\text { biosynthesis }\end{array}$ & auxin & Nitrilase & $\uparrow$ & & $\uparrow \uparrow$ & & & \\
\hline SCEQRTI028H06.g & $\begin{array}{l}\text { hormone } \\
\text { biosynthesis }\end{array}$ & auxin & Nitrilase & & $\downarrow \downarrow$ & $\uparrow \uparrow$ & & & \\
\hline SCRFLRIOI2DI2.g & $\begin{array}{l}\text { hormone } \\
\text { biosynthesis }\end{array}$ & auxin & Nitrilase & $\uparrow$ & $\downarrow$ & $\uparrow \uparrow$ & & & \\
\hline SCVPLR2012A $10 . g$ & $\begin{array}{l}\text { hormone } \\
\text { biosynthesis }\end{array}$ & ethylene & ACC oxidase & $\uparrow$ & $\downarrow \downarrow$ & & & & \\
\hline SCCCRTIOOIEOI.g & $\begin{array}{l}\text { hormone } \\
\text { biosynthesis }\end{array}$ & jasmonic acid & Lipoxygenase & $\downarrow$ & $\downarrow \downarrow \downarrow \downarrow$ & $\downarrow \downarrow$ & & $\downarrow \downarrow \downarrow$ & $\downarrow \downarrow \downarrow$ \\
\hline SCJFRTI007H07.g & $\begin{array}{l}\text { hormone } \\
\text { biosynthesis }\end{array}$ & jasmonic acid & Lipoxygenase & $\downarrow$ & $\downarrow$ & & & & \\
\hline SCCCLRIC03G0I.g & $\begin{array}{l}\text { hormone } \\
\text { biosynthesis }\end{array}$ & jasmonic acid & $\begin{array}{l}\text { Omega- } 6 \text { fatty acid } \\
\text { desaturase }\end{array}$ & $\downarrow$ & $\downarrow$ & $\uparrow \uparrow$ & $\uparrow \uparrow$ & & \\
\hline SCCCAM2004G02.g & $\begin{array}{l}\text { hormone- } \\
\text { related }\end{array}$ & auxin & $\begin{array}{l}\text { Auxin transport/ } \\
\text { auxin eflux carrier } \\
\text { (OsPINIc) }\end{array}$ & $\downarrow$ & & & & & \\
\hline SCCCLR2002F08.g & $\begin{array}{l}\text { hormone- } \\
\text { related }\end{array}$ & auxin & $\begin{array}{l}\text { dormancy/auxin } \\
\text { associated family } \\
\text { (auxin-repressed) }\end{array}$ & $\downarrow$ & $\uparrow \uparrow$ & & & & \\
\hline
\end{tabular}


Table I: Selection of SAS showing differential expression when high and low Brix plants were compared or when mature and immature internodes were compared. (Continued)

\begin{tabular}{|c|c|c|c|c|c|c|c|c|c|}
\hline SCBGLR 1023D05.g & pathogenicity & R-gene transduction & $\begin{array}{l}\text { Zinc finger protein } \\
\text { (LSDI) }\end{array}$ & $\uparrow$ & $\downarrow \downarrow \downarrow$ & $\downarrow \downarrow$ & & $\uparrow \uparrow \uparrow$ & \\
\hline SCAGLRI043F02.g & $\begin{array}{l}\text { protein } \\
\text { metabolism }\end{array}$ & $\begin{array}{l}\text { calmodulin-binding } \\
\text { protein }\end{array}$ & HSP70 (heat shock) & $\uparrow \uparrow$ & $\downarrow$ & $\uparrow \uparrow$ & & & \\
\hline SCCCCL3I20G07.g & $\begin{array}{l}\text { protein } \\
\text { metabolism }\end{array}$ & $\begin{array}{l}\text { calmodulin-binding } \\
\text { protein }\end{array}$ & HSP70 (heat shock) & $\uparrow$ & & $\uparrow \uparrow$ & & & \\
\hline SCCCRZI003A03.g & $\begin{array}{l}\text { protein } \\
\text { metabolism }\end{array}$ & $\begin{array}{l}\text { calmodulin-binding } \\
\text { protein }\end{array}$ & HSP70 (heat shock) & & $\uparrow$ & & & & \\
\hline SCEQRT2099H0I.g & protein kinase & calcium-dependent & ScCDPK-27 & & $\downarrow$ & & & & \\
\hline SCVPAMI055AI2.g & protein kinase & casein kinase & ScCKI-II & $\uparrow$ & $\downarrow$ & $\uparrow \uparrow$ & & & \\
\hline SCCCLRIC04G08.g & protein kinase & casein kinase & ScCKI-3 & $\uparrow$ & & & & & \\
\hline SCCCLR I022H07.g & protein kinase & cell cycle-related & ScCDK-II & & $\downarrow$ & & & & \\
\hline SCBGLRI096C08.g & protein kinase & cell cycle-related & ScCDK-18 & & $\downarrow$ & & & & \\
\hline SCVPRT208IG05.g & protein kinase & cell cycle-related & ScCDK-3 & & $\downarrow$ & & & & \\
\hline SCRLFLIOI2BI0.g & protein kinase & cell cycle-related & ScCDK-6 & & $\downarrow$ & & & & \\
\hline SCSBAMI084E0I.g & protein kinase & $\begin{array}{l}\text { MAPK/MAPKK/ } \\
\text { MAPKKK }\end{array}$ & ScMAPK-4 & $\uparrow$ & $\uparrow \uparrow$ & & $\downarrow \downarrow$ & & \\
\hline SCEPAMI020A03.g & protein kinase & other & ScATNI-2 & $\downarrow$ & & & & & \\
\hline SCVPCL6042B07.g & protein kinase & other & $\begin{array}{l}\text { ScCyclin G- } \\
\text { associated kinase-like } \\
\text { protein-I }\end{array}$ & & $\downarrow$ & & & & \\
\hline SCJFRZ2032C08.g & protein kinase & SNF-like kinase & ScCIPK-14 & & $\uparrow$ & $\uparrow \uparrow$ & & & \\
\hline SCBFSB I046D04.g & protein kinase & SNF-like kinase & ScCIPK-16 & $\uparrow$ & & & & $\downarrow \downarrow \downarrow$ & \\
\hline SCMCRT2I03B04.g & protein kinase & SNF-like kinase & ScCIPK-2I & $\uparrow \uparrow$ & $\uparrow$ & $\downarrow \downarrow$ & & $\downarrow \downarrow$ & \\
\hline SCCCLRIC05B07.g & protein kinase & SNF-like kinase & ScCIPK-3 & $\uparrow$ & & $\uparrow \uparrow$ & & $\downarrow \downarrow \downarrow$ & $\downarrow \downarrow \downarrow$ \\
\hline SCJLRZI023H04.g & protein kinase & SNF-like kinase & ScCIPK-9 & & $\downarrow \downarrow$ & $\downarrow \downarrow$ & & & \\
\hline SCEPRZI009CI0.g & protein kinase & SNF-like kinase & ScOSA PK-I & & $\downarrow \downarrow$ & & & $\downarrow \downarrow$ & $\downarrow \downarrow$ \\
\hline SCCCSTI004A07.g & protein kinase & SNF-like kinase & ScOSA PK-7 & & $\downarrow$ & & & & \\
\hline SCACLR2007G02.g & protein kinase & SNF-like kinase & ScPKABAI-I & $\uparrow \uparrow$ & & & & $\downarrow \downarrow$ & $\downarrow \downarrow \downarrow$ \\
\hline SCRFLR I034G06.g & protein kinase & SNF-like kinase & ScPKABAI-3 & $\uparrow$ & & & $\downarrow \downarrow$ & $\downarrow \downarrow \downarrow$ & $\downarrow \downarrow \downarrow$ \\
\hline SCJFRZ2032G0I.g & protein kinase & SNF-like kinase & ScSnRKI-2 & & $\downarrow \downarrow$ & $\downarrow \downarrow$ & & $\uparrow$ & \\
\hline SCCCCL5002BI0.g & protein kinase & undefined & ScPK-BI2 & & $\downarrow \downarrow \downarrow$ & & & & \\
\hline SCJLLR I 054C03.g & protein kinase & undefined & ScPK-BIII7 & $\uparrow$ & & & & & \\
\hline SCMCSD206ID05.g & protein kinase & $\begin{array}{l}\text { undefined } \\
\text { unclassified }\end{array}$ & ScUPK-46 (CIPK) & $\downarrow$ & & & & & \\
\hline SCCCLBI00ID03.g & $\begin{array}{l}\text { protein } \\
\text { phosphatase }\end{array}$ & $\begin{array}{l}\text { serine/threonine } \\
\text { PPM family }\end{array}$ & $\begin{array}{l}\text { PP2A/Catalytic } \\
\text { Subunit }\end{array}$ & & $\downarrow$ & & & & \\
\hline SCEZLR I052F07.g & $\begin{array}{l}\text { protein } \\
\text { phosphatase }\end{array}$ & $\begin{array}{l}\text { serine/threonine } \\
\text { PPM family }\end{array}$ & PP2A/Subunit A & & $\downarrow$ & & & & \\
\hline SCEPRZI0I0E06.g & $\begin{array}{l}\text { protein } \\
\text { phosphatase }\end{array}$ & $\begin{array}{l}\text { serine/threonine } \\
\text { PPM family }\end{array}$ & PP2C-like & $\downarrow \downarrow$ & $\downarrow$ & $\uparrow \uparrow$ & $\uparrow \uparrow$ & $\downarrow \downarrow \downarrow$ & $\downarrow \downarrow \downarrow$ \\
\hline SCEZHRI088E02.g & $\begin{array}{l}\text { protein } \\
\text { phosphatase }\end{array}$ & tyrosine phosphatase & $\begin{array}{l}\text { Dual Specificity } \\
\text { Protein Phosphatases } \\
\text { (DSPP) }\end{array}$ & $\uparrow \uparrow \uparrow$ & $\downarrow$ & $\uparrow \uparrow$ & & $\downarrow \downarrow \downarrow$ & $\downarrow \downarrow \downarrow$ \\
\hline SCMCSTI05IF08.g & $\begin{array}{l}\text { protein } \\
\text { phosphatase }\end{array}$ & tyrosine phosphatase & $\begin{array}{l}\text { Tyrosine Specific } \\
\text { Protein Phosphatases } \\
\text { (PTP) }\end{array}$ & & & $\downarrow \downarrow$ & & & \\
\hline SCSBHRI056H08.g & receptor & ethylene & EIN2 & & $\uparrow$ & & & & \\
\hline SCUTLR2023D06.g & $\begin{array}{l}\text { transcription } \\
\text { factor }\end{array}$ & CСAAT & $\mathrm{ScCA} 2 \mathrm{P} 5$ & $\uparrow$ & & & & & \\
\hline SCCCLRI066G08.g & $\begin{array}{l}\text { transcription } \\
\text { factor }\end{array}$ & $\begin{array}{l}\text { HGM } \\
\text { (high mobility group } \\
\text { protein) }\end{array}$ & & $\uparrow$ & & $\downarrow \downarrow$ & & & \\
\hline SCBFADI046D0I.g & $\begin{array}{l}\text { transcription } \\
\text { factor }\end{array}$ & $\begin{array}{l}\text { HLH } \\
\text { (helix-loop-helix) }\end{array}$ & ScbHLHI & & $\downarrow \downarrow$ & & & & \\
\hline SCCCRZI00IH05.g & $\begin{array}{l}\text { transcription } \\
\text { factor }\end{array}$ & $\begin{array}{l}\text { HLH } \\
\text { (helix-loop-helix) }\end{array}$ & ScbHLH7 & $\uparrow \uparrow$ & & $\downarrow \downarrow$ & & $\downarrow \downarrow \downarrow$ & $\downarrow \downarrow \downarrow$ \\
\hline SCAGLRI02IGI0.g & $\begin{array}{l}\text { transcription } \\
\text { factor }\end{array}$ & homeobox & $\mathrm{ScHB} 2$ & & $\downarrow \downarrow$ & & & $\downarrow \downarrow \downarrow$ & $\downarrow \downarrow \downarrow$ \\
\hline SCRLAMI0IOD08.g & $\begin{array}{l}\text { transcription } \\
\text { factor }\end{array}$ & homeobox & ScHB4I & & $\downarrow \downarrow$ & & & & \\
\hline SCEZLBIOIOEI0.g & $\begin{array}{l}\text { transcription } \\
\text { factor }\end{array}$ & $\begin{array}{l}\text { hormone-related/ } \\
\text { auxin }\end{array}$ & ScABI40 & $\downarrow$ & & & & & \\
\hline
\end{tabular}


Table I: Selection of SAS showing differential expression when high and low Brix plants were compared or when mature and immature internodes were compared. (Continued)

\begin{tabular}{|c|c|c|c|c|c|c|c|c|}
\hline SCCCLRI024FI0.g & $\begin{array}{l}\text { transcription } \\
\text { factor }\end{array}$ & $\begin{array}{l}\text { hormone-related/ } \\
\text { auxin }\end{array}$ & ScARF46 & & $\downarrow$ & & & \\
\hline SCCCRZI00IGI0.g & $\begin{array}{l}\text { transcription } \\
\text { factor }\end{array}$ & $\begin{array}{l}\text { hormone-related/ } \\
\text { Aux/IAA }\end{array}$ & ScAUXII34 & & $\downarrow \downarrow \downarrow \downarrow$ & $\downarrow \downarrow$ & $\downarrow \downarrow \downarrow$ & $\downarrow \downarrow \downarrow$ \\
\hline SCVPLR2005H03.g & $\begin{array}{l}\text { transcription } \\
\text { factor }\end{array}$ & $\begin{array}{l}\text { hormone-related/ } \\
\text { Aux/IAA }\end{array}$ & & & $\downarrow \downarrow$ & & & \\
\hline SCJFRZ2009F04.g & $\begin{array}{l}\text { factor } \\
\text { transcription }\end{array}$ & $\begin{array}{l}\text { hormone-related/ } \\
\text { Aux/IAA }\end{array}$ & & & $\downarrow$ & & & \\
\hline SCJLLR I054C09.g & $\begin{array}{l}\text { transcription } \\
\text { factor }\end{array}$ & $\begin{array}{l}\text { hormone-related/ } \\
\text { Aux/IAA }\end{array}$ & & & $\downarrow \downarrow$ & & & \\
\hline SCUTST3086B02.g & $\begin{array}{l}\text { transcription } \\
\text { factor }\end{array}$ & $\begin{array}{l}\text { hormone-related/ } \\
\text { ethylene/AP2/ERE } \\
\mathrm{BP}\end{array}$ & ScEREB59 & & $\downarrow$ & & & \\
\hline SCCCLRIOOIDI0.g & $\begin{array}{l}\text { transcription } \\
\text { factor }\end{array}$ & $\begin{array}{l}\text { hormone-related/ } \\
\text { ethylene/AP2/ERE } \\
\text { BP }\end{array}$ & DRE binding factor 2 & & $\uparrow$ & $\uparrow \uparrow$ & & \\
\hline SCBGFL4052C I I.g & $\begin{array}{l}\text { transcription } \\
\text { factor }\end{array}$ & $\begin{array}{l}\text { hormone-related/ } \\
\text { ethylene }\end{array}$ & ScEILI & & $\downarrow$ & & & \\
\hline SCCCRZI004HI2.g & $\begin{array}{l}\text { transcription } \\
\text { factor }\end{array}$ & $\begin{array}{l}\text { hormone-related/ } \\
\text { ethylene }\end{array}$ & ScEIL2 & $\downarrow$ & $\downarrow$ & & & \\
\hline SCCCRZ2C03DII.g & $\begin{array}{l}\text { transcription } \\
\text { factor }\end{array}$ & $\begin{array}{l}\text { hormone-related/ } \\
\text { gibberellin }\end{array}$ & ScGRAS7I & & $\downarrow \downarrow$ & & & \\
\hline SCEPRZI008F02.g & $\begin{array}{l}\text { transcription } \\
\text { factor }\end{array}$ & $\begin{array}{l}\text { LIM } \\
\text { (protein-protein } \\
\text { interaction) }\end{array}$ & & $\downarrow$ & $\downarrow \downarrow$ & & & \\
\hline SCQGLRI085G I0.g & $\begin{array}{l}\text { transcription } \\
\text { factor }\end{array}$ & MADS & ScMADSI7 & & $\uparrow$ & $\downarrow \downarrow$ & & \\
\hline SCSFADI I 24E07.g & $\begin{array}{l}\text { transcription } \\
\text { factor }\end{array}$ & MYB & ScMYB70 & & $\uparrow$ & & & \\
\hline SCRURT20IOAI0.g & $\begin{array}{l}\text { transcription } \\
\text { factor }\end{array}$ & MYB & ScMYBI20 & & $\downarrow$ & & & \\
\hline SCCCLR2003E10.g & $\begin{array}{l}\text { transcription } \\
\text { factor }\end{array}$ & $\begin{array}{l}\text { NAM } \\
\text { (no apical meristem) }\end{array}$ & ScNAC27 & $\downarrow \downarrow$ & & & $\downarrow \downarrow \downarrow$ & $\downarrow \downarrow \downarrow$ \\
\hline SCRUADII32D09.g & $\begin{array}{l}\text { transcription } \\
\text { factor }\end{array}$ & $\begin{array}{l}\text { NAM } \\
\text { (no apical meristem) }\end{array}$ & ScNAC5I & & & & & \\
\hline SCACLRII30H08.g & $\begin{array}{l}\text { transcription } \\
\text { factor }\end{array}$ & zinc finger protein & ScYABI 6 & & $\downarrow$ & & & \\
\hline SCEZST3I47AI0.g & $\begin{array}{l}\text { transcription } \\
\text { factor }\end{array}$ & zinc finger protein & $\mathrm{ScC} 3 \mathrm{H} 84$ & $\downarrow$ & $\downarrow$ & & & \\
\hline SCCCCL4003D08.g & $\begin{array}{l}\text { transcription } \\
\text { factor }\end{array}$ & zinc finger protein & $\mathrm{ScC} 3 \mathrm{H} 95$ & & $\downarrow$ & & & \\
\hline SCQGRZ30IID06.g & $\begin{array}{l}\text { transcription } \\
\text { factor }\end{array}$ & $\begin{array}{l}\text { zinc finger protein/ } \\
\text { alfin-like }\end{array}$ & ScALF9 & & $\downarrow$ & & & \\
\hline SCCCRZI002E08.g & stress & $\begin{array}{l}\text { drought and cold } \\
\text { response }\end{array}$ & $\begin{array}{l}\text { Aquaporin } \\
\text { (plasma membrane) }\end{array}$ & $\downarrow$ & $\downarrow \downarrow$ & & & \\
\hline SCCCST300IHI2.g & stress & $\begin{array}{l}\text { drought and cold } \\
\text { response }\end{array}$ & $\begin{array}{l}\text { Áquaporin } \\
\text { (plasma membrane) }\end{array}$ & $\uparrow$ & $\downarrow \downarrow$ & & & \\
\hline SCEQRT2I00B02.g & stress & $\begin{array}{l}\text { drought and cold } \\
\text { response }\end{array}$ & $\begin{array}{l}\text { Aquaporin } \\
\text { (plasma membrane) }\end{array}$ & $\uparrow$ & $\downarrow \downarrow$ & & & \\
\hline SCCCLRI024C03.g & stress & $\begin{array}{l}\text { drought and cold } \\
\text { response }\end{array}$ & $\begin{array}{l}\text { Aquaporin } \\
\text { (tonoplast intrinsic } \\
\text { protein) }\end{array}$ & $\downarrow$ & $\downarrow$ & & & \\
\hline SCCCRZI00IF02.g & stress & $\begin{array}{l}\text { drought and cold } \\
\text { response }\end{array}$ & $\begin{array}{l}\text { Aquaporin } \\
\text { (tonoplast intrinsic } \\
\text { protein) }\end{array}$ & $\downarrow$ & $\downarrow$ & & & \\
\hline SCQGLRI085FII.g & stress & drought-induced & Dehydrin & $\downarrow$ & $\downarrow \downarrow \downarrow$ & $\uparrow \uparrow$ & $\downarrow \downarrow \downarrow$ & $\downarrow \downarrow \downarrow$ \\
\hline SCCCLR2C0IF06.g & stress & wound-induced & $\begin{array}{l}\text { wound-responsive } \\
\text { family protein }\end{array}$ & $\uparrow \uparrow \uparrow$ & $\uparrow$ & & $\uparrow \uparrow \uparrow$ & $\uparrow \uparrow \uparrow$ \\
\hline
\end{tabular}

The table also shows differential expression of the same SAS as seen in [3I] for plants submitted to drought and ABA treatment. Differential expression refers to CDNA microarray analysis except for the last two columns, which refer to GRT-PCR data obtained in samples of plantlets treated with sucrose or glucose. The table lists a selection of SAS whose expression was enriched or decreased in two technical replicates for each biological sample. For a complete list see additional file 2. The up arrow indicates that the SAS is more expressed, the down arrow indicates that the SAS is less expressed. The number of arrows indicates the number of hybridizations. 
A
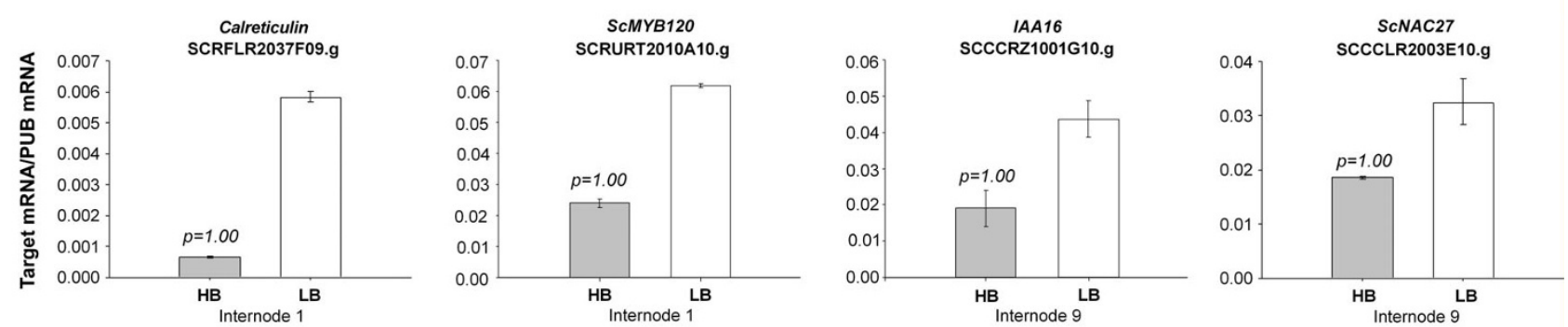

B
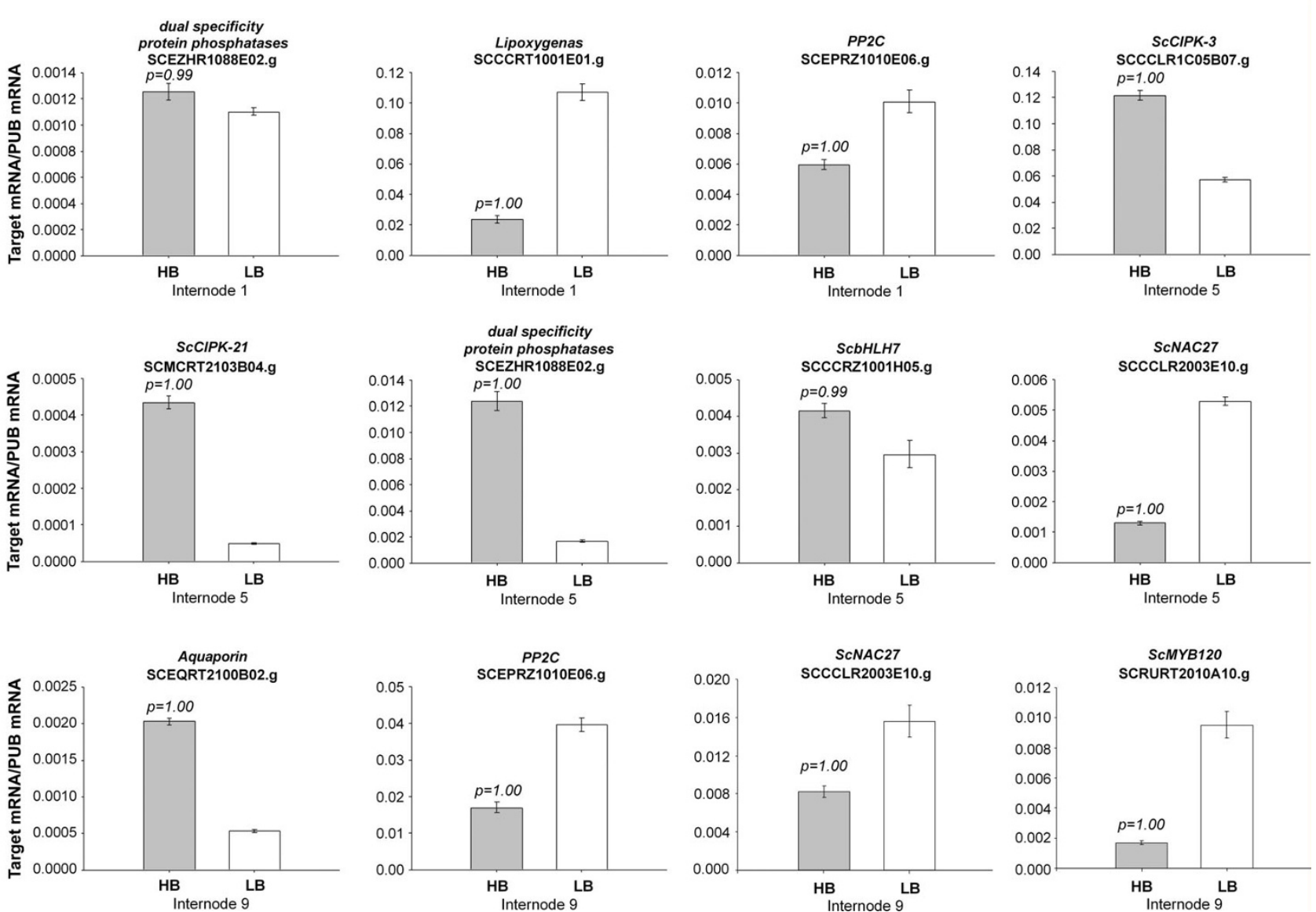

Figure 2

Real Time PCR (qRT-PCR) analysis of Populations gene expression. The y axis refers to the relative expression ratio between target mRNA versus the reference mRNA (polyubiquitin-PUB SCCCST200IG02.g). The relative expression levels were determined in Internode I, 5 and 9 tissues from a pool of the eight individuals with the highest Brix measures (HB) and the eight individuals with the lowest Brix measures (LB) from Population I (A) and from a pool of the seven individuals with the highest Brix measures (HB) and the seven individuals with the lowest Brix measures (LB) from Population 2 (B). The reactions for the target mRNA and reference mRNA were carried out in parallel and each reaction was performed in triplicates. Error bars were calculated as described previously [3I]. The transcript levels for the reference genes were verified not to vary in response to the treatments. The values of $P$ correspond to the probability $\operatorname{Pr}(H B>L B)$ and $\operatorname{Pr}(H B<L B)$ for up- and down-regulated genes, respectively. The SAS was considered differentially expressed when $P \geq 0.95$.

affected by sucrose, of which six were also found to be regulated by 3\% manitol (osmotic control) and thus, were not considered as true sucrose-responsive genes (see Additional file 3). Figure 6 shows the expression pattern of fifteen of these genes. Among the twenty-four sucroseregulated genes, nineteen were also found to respond to glucose, indicating a significant overlap between these two signaling pathways (see Additional file 3 and Figure 6 ). This is not unexpected since sucrose can be readily converted to glucose and sucrose-specific responsive pathways have been identified previously. The five genes, identified here as genuine sucrose-regulated genes, include 

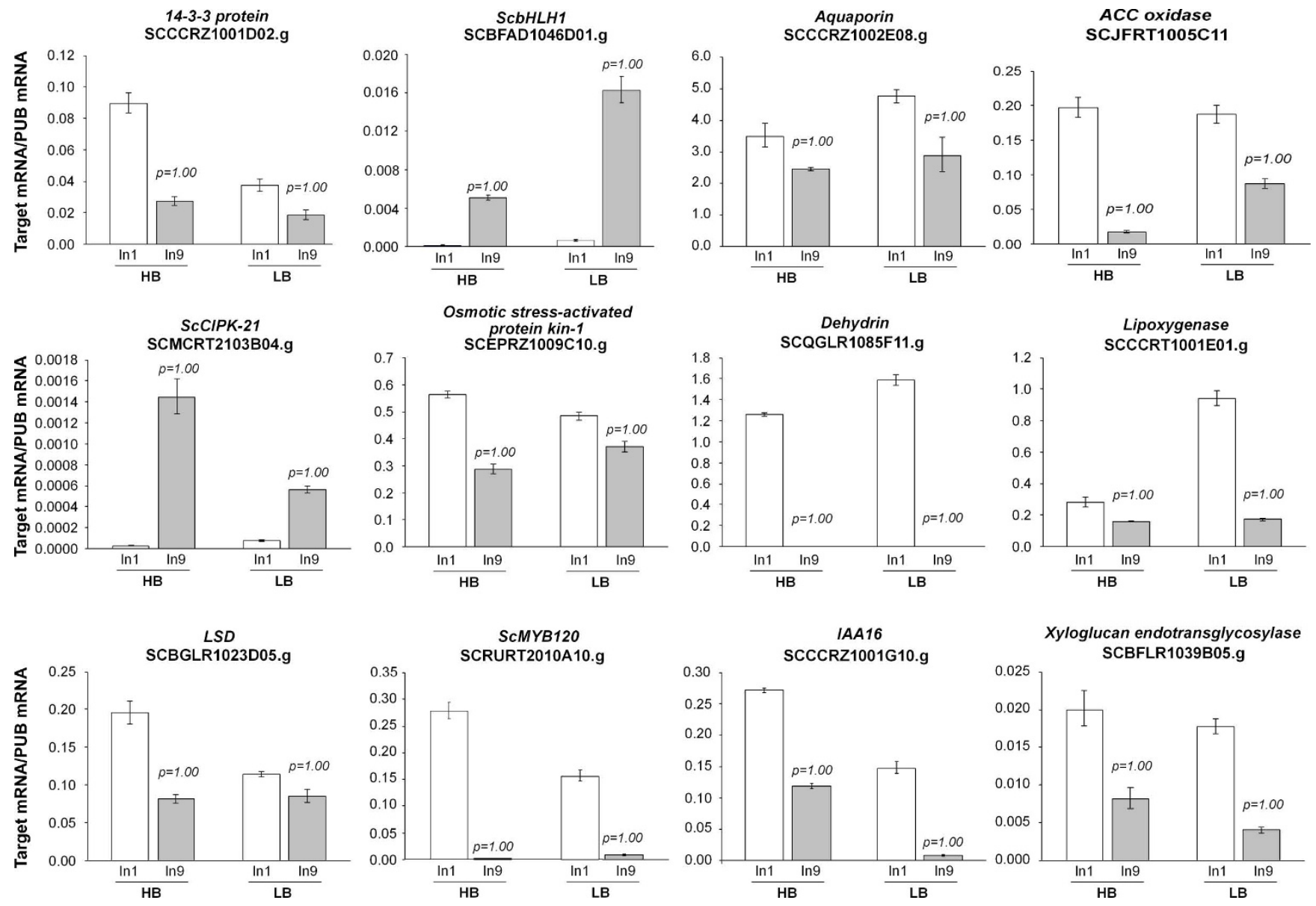

Figure 3

Real Time PCR (qRT-PCR) analysis of internode developmental gene expression. The $y$ axis refers to the relative expression ratio between target mRNA versus the reference mRNA (polyubiquitin SCCCST200 IG02.g). The relative expression levels were determined in Internode $I$ and 9 tissues from a pool of the seven individuals with the highest Brix measures (HB) and the seven individuals with the lowest Brix measures (LB) of Population 2. All reactions were carried out in parallel and each reaction was performed in triplicates. Error bars were calculated as described previously [3I]. The transcript levels for the reference genes were verified to not vary in response to the treatments. The $P$ values correspond to the probability $\operatorname{Pr}(M \mid>I I)$ and $\operatorname{Pr}(M \mid<I)$ for up- and down-regulated genes, respectively when $\ln 9$ and InI samples were compared. The values of $P$ were calculated for the HB and LB pools of plants independently. The SAS was considered differentially expressed when $P$ $\geq 0.95$.

three SNF1-like kinases, a pathogen-response related protein and a multidrug resistance ABC transporter (see Additional file 3). A weak overlap with ABA signaling was detected, since only three sucrose/glucose-regulated genes were also modulated by ABA (Table 1). Finally, we noticed that thirteen of the twenty-four genes exhibited opposite regulatory responses in high Brix genotypes and/ or mature internodes as compared to the short-term sugar-induced regulation in seedlings (data not shown). Together, these data establish the existence of a correlation between high sucrose content and early sucrose and/ or glucose-responsive genes, some of which may be relays of signal transduction pathways triggered by these sugars.
In addition, we sought to obtain some insight into the extent to which the short term sucrose and/or glucose regulatory cascade is conserved between sugarcane, a monocot and Arabidopsis thaliana (Arabidopsis), a model eudicot organism. Therefore, we compared the data obtained in this study on sugarcane seedlings with results described for Arabidopsis seedlings under similar experimental conditions (3\% glucose [30] or $0,5 \%$ sucrose [34]). Among the twenty-four sugar-regulated sugarcane genes, six of them, along with their eight orthologues in Arabidopsis (forming five groups of orthologues) were found to be similarly regulated by glucose and/or sucrose (see Additional file 4 and Additional file 5). The groups of 

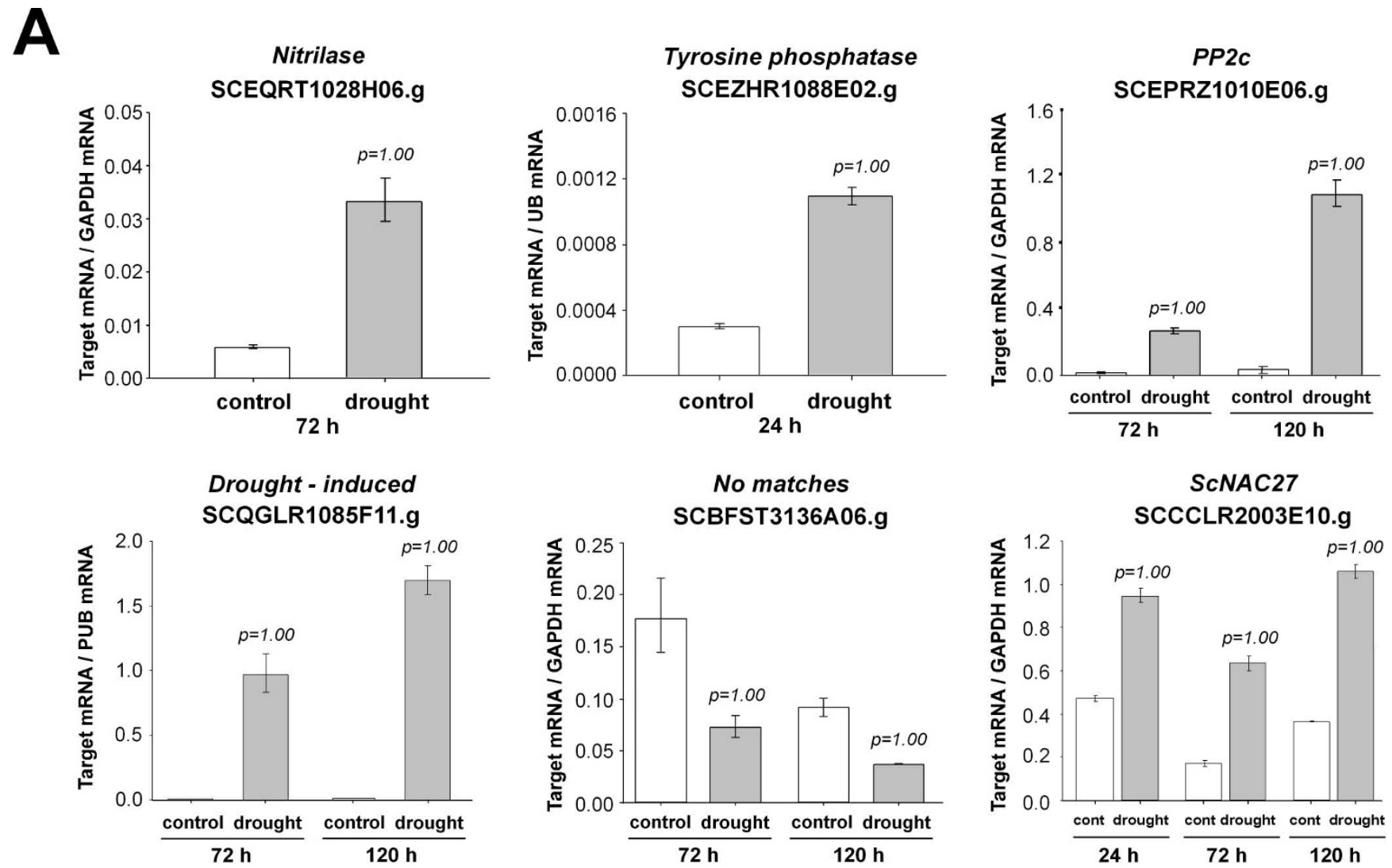

B
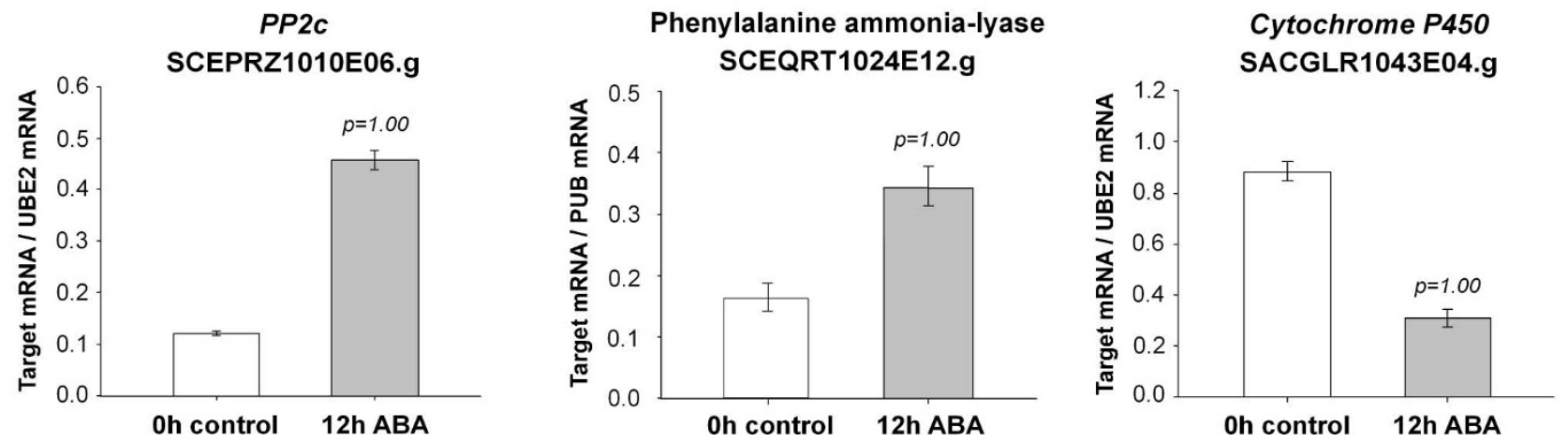

Figure 4

Real Time PCR (qRT-PCR) analysis of drought and ABA-responsive gene expression. The $y$ axis refers to the relative expression ratio between target mRNA versus the reference mRNA (polyubiquitin SCCCST200 IG02.g; GAPDH Gene ID: 542367; UBE2 SCBGLR 1002D06.g) in sugarcane plants treated with ABA for $12 \mathrm{~h}$ or drought conditions for 24, 72 or $120 \mathrm{~h}$. The reactions for the target mRNA and reference mRNA were carried out in parallel and each reaction was performed in triplicates. Error bars were calculated as described previously [3I]. The transcript levels for the reference genes were verified to not vary in response to the treatments. The values of $\mathrm{P}$ correspond to the probability $\mathrm{Pr}$ (Treated $>\mathrm{Control})$ and $\mathrm{Pr}$

(Treated<Control) for up- and down-regulated genes, respectively. The SAS was considered differentially expressed when $\mathrm{P} \geq$ 0.95 .

orthologues correspond to SNF1-like kinases (SCRFLR1034G06.g and SCACLR2007G02.g - At1g 78290), two calreticulin genes (SCRFLR2037F09.g At1g56340 and At1g09210), an auxin/IAA transcription factor gene (SCCCRZ1001G10.g - At3g04730), a defense and cell wall-related gene encoding a phenyl ammonialyase (SCEQRT1024E12.g - At2g37040, At3g53260, At3g10340) and a dehydrin gene (SCQGLR1085F11.g - 

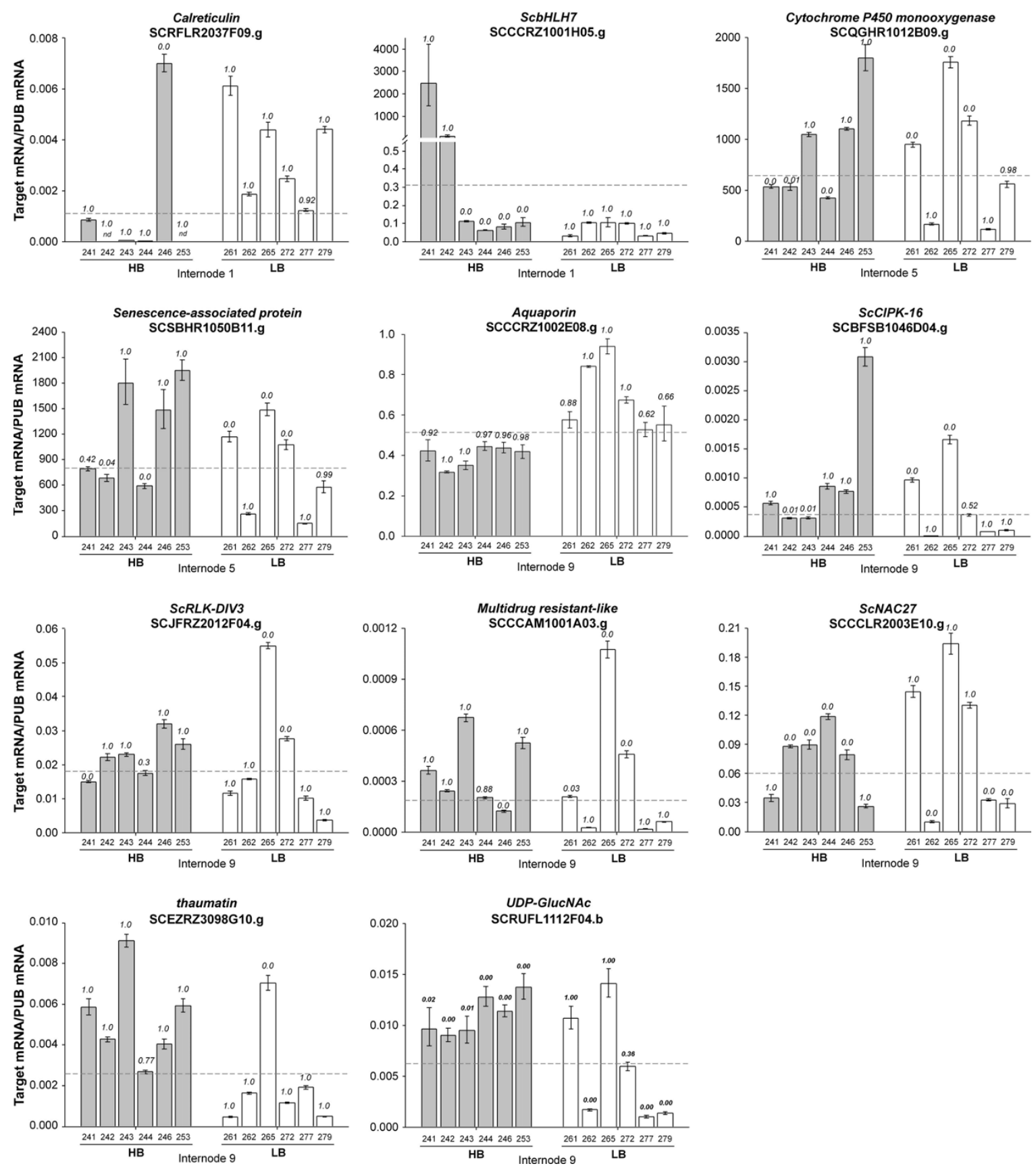

\section{Figure 5}

Real Time PCR (qRT-PCR) analysis of individual genotypes gene expression. The $y$ axis refers to the relative expression ratio between target mRNA versus the reference mRNA (polyubiquitin SCCCST200IG02.g). The relative expression levels were determined in Internode I, 5 and 9 tissues from six individuals with the highest Brix measures (CTC98-24I, CTC98-242, СTC98-243, СTC98-244, СTC98-246 and CTC98-253) and six individuals with the lowest Brix measures (CTC98-26I, CTC98-262, CTC98-265, CTC98-272, CTC98-277 and CTC98-279) of Population 2. All reactions were carried out in parallel and each reaction was performed in triplicates. Error bars were calculated as described previously [3I]. The transcript levels for the reference genes were verified to not vary in response to the treatments. The significance of differential gene expression was determined considering normal distributions for each tested condition and comparing them to the average expression for all samples (dotted line). The values of $\mathrm{P}$ correspond to the probability $\operatorname{Pr}(\mathrm{GenotypeX}>\mathrm{average})$ and $\mathrm{Pr}$ (GenotypeX<average) for up- and down-regulated genes. $P$ values were calculated for each genotype independently. The SAS was considered differentially expressed when $\mathrm{P} \geq 0.95$. 

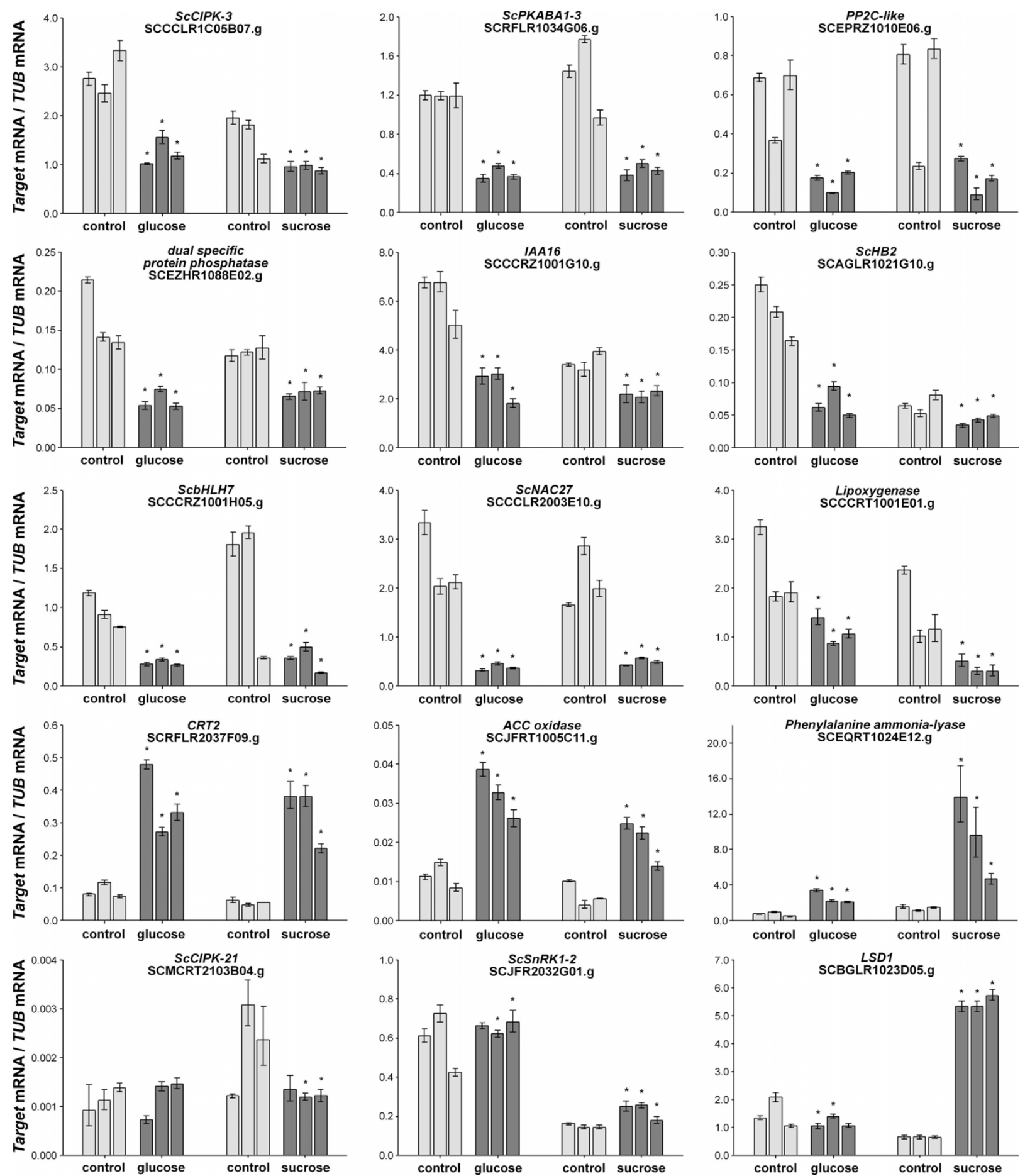

Figure 6

Quantitative PCR (qRT-PCR) analysis of sucrose and glucose responsive genes. The $y$ axis refers to the relative expression ratio between target mRNA versus the reference mRNA (tubulin SCCCRZI002H03.g) for 3 different experiments in sugarcane thirteen-old day seedlings treated with $3 \%$ glucose and $3 \%$ sucrose for $4 \mathrm{~h}$. RI, R2 and R3 refers to three control and three sucrose and glucose independent treatments. Error bars were calculated as described previously [3I]. The transcript levels for the reference genes were verified to not vary in response to the treatments. The values of $\mathrm{P}$ correspond to the probability $\operatorname{Pr}($ Treated $>$ Control) and $\operatorname{Pr}$ (Treated<Control) for up- and down-regulated genes, respectively. The SAS was considered differentially expressed when $\mathrm{P} \geq 0.95$. 
At3g50980) (see Additional file 4). Furthermore, two Arabidopsis genes, the CUC1/NAC-type transcription factor (At3g1550) and a wound-responsive gene (At4g10270) and their closely related respective sugarcane homologues (SCCCLR2003E10.g and SCCCLR2C01F06.g) were found to be similarly regulated by sugars (Table 1 ).

\section{Discussion}

Sugarcane partitions carbon into sucrose that can accumulate to $0.7 \mathrm{M}$ in culms [35]. This unique characteristic has been exploited and improved by humans through breeding. Studies that shed light on the molecular mechanisms behind this feature include gene expression and signaling studies on sink and source regulation [36], QTL studies for sucrose accumulation [37] and gene expression profiling during internode maturation [10-12,38]. Such studies indicated that genes associated with sucrose metabolism are not abundantly expressed in culm tissues while genes related to synthesis and catalysis of sucrose are turned off during internode maturation. Genes involved in cellulose synthesis, cell wall metabolism and lignification are also regulated during this process. The activity of genes associated with internode development was evaluated in genotypes of $S$. robustum (which does not accumulate sucrose to high levels), S. officinarum and in a hybrid [39]. Mature internodes of all three genotypes showed decreased expression of cell wall metabolism-associated genes and increased expression of genes related to sucrose metabolism. While the general conclusion of these studies does not appear to be in agreement, it is important to note that the genotypes, environment and age of plants used were different and that a larger sampling may be necessary to define gene profiles in sugarcane.

In this work, we evaluated mature and immature internodes of thirty genotypes using cDNA microrrays and qRT-PCR. Genes associated with sucrose content were defined through the analysis of segregating populations selected for one or three generations [40]. Internodes 1, 5 and 9 (In1, 5 and 9) were collected from plants grown in the field. Among the genes found to be differentially expressed were those related to hormone signaling (auxin, ethylene, jasmonates), stress responses (drought, cold, oxidative), cell wall metabolism, calcium metabolism, protein kinases, protein phosphatases and transcription factors. We compared high Brix plants against low Brix plants by hybridizing pairwise the In 1 , In 5 and In 9 tissues directly (HB vs LB hybridizations) or by hybridizing mature against immature internodes (MI vs II). We validated gene expression by qRT-PCR in pools of clones and many individual genotypes. We also investigated if genes associated with sucrose content were responsive to sucrose or glucose treatments. Many of the sucrose-associated genes that are regulated during development are associated with drought responses or are modulated by ABA or sugars, as discussed below (see Additional file 2 and Table 1).

\section{Protein kinases and calcium signaling}

Protein phosphorylation appears to play a predominant role in sucrose accumulation and culm development. We have previously categorized sugarcane proteins with a PKinase domain using a phylogenetic approach and named sugarcane protein kinases (PKs) according to the groups obtained, similarity to other kinases and additional domains observed [31]. We now add evidence that several of these genes are regulated during culm development.

A total of fifty-four genes corresponding to PKs, protein phosphatases (PPases) or receptor-like kinases (RLKs) were differentially expressed in high Brix plants or during culm maturation (see Additional file 2). ScMAPK-4 (SCSBAM1084E01.g) was more highly expressed in high Brix and mature internodes (Table 1). A MAPK kinase was reported to be involved in the regulation of source metabolism by glucose and stress, which is an indication that ScMAPK-4 might be important in establishing sink-source relationships in sugarcane $[36,41]$. The most predominant PK category altered is the SNF1-like kinase family of proteins. In yeast, SNF1 regulates the expression of genes coding for carbohydrate metabolism and other metabolic enzymes [42]. In plants, SNF1-related kinases have been named SnRK1 [43] and comprise three distinct sub-families (SnRK1, SnRK2 and SnRK3). In sugarcane, we have identified members of all three sub-families [31]. Analogous to SNF1, plant SnRK1s also regulate carbon metabolism at the level of gene expression. At least three important biosynthetic enzymes have been identified as biological substrates of SnRK1s: hydroxymethylglutarylCoA reductase (HMG-CoA reductase) [44]; sucrose-phosphate synthase [45] and nitrate reductase [46]. It is possible to make a direct parallel between sucrose accumulation and the gene expression levels for an ScSnRK1 (SCJFRZ2032G01.g). ScSnRK1-2 and four 14-33 proteins of the GF14 type (SCCCLR1022D05.g, SCCCRZ1001D02.g, SCEQRT1031D02.g and SCEQRT1025D06.g) were expressed at lower levels in mature internodes (Table 1). 14-3-3 proteins, together with a SnRK1, phosphorylate and inhibit the enzyme sucrose phosphate synthase (SPS) in vitro $[45,47]$. Our findings suggest that the decrease in the expression of these genes in the mature internodes may allow for increased sucrose accumulation. We also observed that ScSnRK1-2 was induced by sucrose treatment, while most of the ScCIPKs and ScPKABA and ScOSAPK genes were repressed (Table 1). This is an interesting finding that may 
functionally distinguish the pathways triggered by these kinases in response to sucrose and stress.

Members of the SnRK2 and SnRK3 sub-family including two Osmotic Stress-Activated Kinases - OSA-PK (SCEPRZ1009C10.g and SCCCST1004A07.g) and three CBL-interacting Protein Kinases - CIPK (SCJFRZ 2032C08.g, SCMCRT2103B04.g and SCJLRZ1023H04.g) were identified as developmentally regulated during culm maturation (Table 1). Most importantly, three CIPKs (SCBFSB1046D04.g, SCMC RT2103B04.g, SCCC LR1C05B07.g) were more highly expressed in high Brix plants. CBL are regulatory subunits similar to calcineurin that bind to and respond to calcium signals [48]. It has been shown that OSA-PKs and CIPKs mediate drought, osmotic, saline and cold stresses in response to ABA and calcium [49]. Among our differentially expressed genes we found nine genes associated with calcium signaling (SCVPLR1049C09.g, SCCCRZ1C01H06.g, SCJL LR1108 H07.g, SCEZLB1012F10.g, SCCCAM1001A03.g, SCAGL R1043F02.g, SCCCCL3120G07.g, SCCC RZ1003A03.g, SCRFLR2037F09.g) and a calcium-dependent protein kinase (SCEQRT2099H01.g - ScCDPK-27) that also indicates a role for this second messenger in sucrose accumulation in sugarcane (Table 1). Sucrose synthesis control depends on the activity of the sucrose phosphate synthase, which catalyses the synthesis of sucrose 6-phosphate from UDP-glucose and fructose 6-phosphate. Sucrose breakdown depends on the activity of invertase, which breaks down sucrose into glucose and fructose, and on the activity of sucrose synthase, that converts sucrose in fructose and UDP-glucose in the presence of UDP [35]. Several studies have shown that some CDPKs phosphorylate and regulate sucrose synthase [50-53]. Studies on the maize sucrose synthase showed that phosphorylation of this enzyme on the Ser- 15 by CDPKs stimulates the sucrose breakdown activity of this enzyme [50,52]. Besides, CDPKs can phosphorylate residue Ser- 170 of this enzyme directing it to the degradation pathway via proteosome 26S [52,54]. The decrease in expression of ScCDPK-27 in the mature internode correlates well with increased sucrose in this organ. The activity of sucrose synthase modulates the source-drain relationship [55,56], which eventually determines sucrose content in sugarcane internodes. Additionally, some CDPKs can phosphorylate and inactivate the enzyme sucrose phosphate synthase $[57,58]$, which might contribute to lower sucrose in culms when this enzyme is expressed in high levels, such as seen in low Brix genotypes. Since sucrose biosynthesis is a process regulated by calcium, CDPKs and SnRKs, the genes differentially expressed observed in the high Brix genotypes may all contribute and act as critical control points in sucrose accumulation in this grass.

\section{Drought signaling}

We found a prevalence of gene families regulated by ABA, drought and other stresses among the genes associated with sucrose content [33]. Sixty-nine genes associated with sucrose content were identified to be regulated in response to drought and eleven to ABA (see Additional file 2). This is a strong indication that some of the pathways associated with sucrose content and culm development may overlap with stress signaling pathways. A similar finding was described by Casu and colleagues that found many stress-related genes expressed in culms [11]. Overall, around $32 \%$ of the genes previously found to be responsive to drought are associated with sucrose content (Figure 1). It is generally known that sugarcane plants maturation is favoured by the exposure to a period of low water precipitation. It is possible that increased sucrose content is dependent on a drought season and that plants converge the drought and sucrose signaling pathways to sustain growth even during the stress season. Sugars that transduce stress signals or act as osmoprotectants, like fructose, raffinose and trehalose [20] could be central players during this process. A PP from the PP2C family (SCEPRZ1010E06.g) similar to a PPase that transduces the ABA signal was identified as associated with Brix, drought and ABA (Table 1). This PPase was less expressed in high Brix, reduced in the mature internodes and induced by drought and ABA. A similarity search showed that this PP2C is very similar to $A B I 1$ and $A B I 2$ from Arabidopsis thaliana. PP2Cs that are part of the ABA signaling pathway, such as ABI1, ABI2, AtPP2CA and AtP2CHA, have their transcript levels increased by this phytohormone $[59,60]$. Among the processes regulated by ABI1 and ABI2 is stomatal closure, which is certainly one of the first protective measures during drought signaling. Moreover, some of the ABA biosynthesis enzymes are induced by drought and osmotic stress [61]. The fact that sugarcane genes associated with $\mathrm{ABA}$ and drought signaling are differentially regulated in plants with distinct sucrose accumulation capacities is an indicative that the role of $A B A$ is well worth being further verified.

Drought responses vary depending on the duration and intensity of the stimulus and comprehend protective alterations and long term growth changes [13]. Many genes responsive to drought have been catalogued [14-18]. The drought stimulus lead to transient calcium fluxes, the activation of calcium sensors, the accumulation of reactive oxygen species, the activation of the MAPK pathway and the induction of several transcription factors including DREB2A, DREB2B [62] and NAC [63]. We have found, among the genes associated with sucrose content, many components of the gene families mentioned above. A MAPK was more expressed in high Brix and in mature 
internodes and repressed by ABA (SCSBAM1084E01.g), a $D R E B$ was induced during culm maturation (SCCCLR1001D10.g) (Table 1) and over forty stress responsive genes were identified (Additional file 2). A DEHYDRIN TYPE 1 (SCQGLR1085F11.g) regulated by the DREB signaling cascade [64] was dramatically repressed in mature internodes of high and low Brix plants and induced after $72 \mathrm{~h}$ and $120 \mathrm{~h}$ drought treatment (Table 1). A barley dehydrin gene, DHN1, was highly expressed in cells cultured at $25^{\circ} \mathrm{C}$ and $2{ }^{\circ} \mathrm{C}$ in media containing high sucrose but our data indicated the dehydrin expression may not be a consequence to high sucrose since immature internodes do not have high levels of this sugar [65]. Overexpression of DREB2A in Arabidopsis thaliana led to the generation of transgenic plants more tolerant to drought $[66,67]$. It is possible that some of the genotypes may indeed be more resistant to drought and thus able to grow and accumulate more sucrose, but additional experiments are necessary to verify this hypothesis.

\section{Transcription factors and hormone signaling}

We have recently integrated and evaluated the SUCEST and PlantGDB http://planttfdb.cbi.pku.edu.cn/web/ index.php?sp=so EST databases for putative Transcription Factors and identified 2,406 candidate TFs. These were classified into families and can be found at http://gras sius.org[68]. We found twenty-one transcription factors (TFs) regulated during culm development (Table 1 ). The great majority was more expressed in the immature internodes, including two members of the Homeobox Knotted1-homeodomain (SCAGLR1021G10.g and SCRLAM1010D08.g), which have been shown to be involved in developmental processes in maize [69]. Developmentally regulated genes include a homolog (SCBFAD1046D01.g) to anthocyanin regulatory R-S protein containing a helix-loop-helix (HLH) domain, that controls tissue-specific synthesis of anthocyanin pigments [70]. Nine transcription factors were identified as differentially expressed when high Brix and low Brix genotypes were compared including an ARFG (AUXIN RESPONSE FACTOR6a) (SCEZLB1010E10.g), a NAM (NO APICAL MERISTEM) (SCCCLR2003E10.g) and an EIL (ETHYLENE INSENSITIVE3-LIKE) (SCCCRZ1004H12.g) (Table $1)$. The NAM transcript was less abundant in both populations analysed, negatively regulated by sucrose and glucose treatment and induced by drought (Table 1 and Figure 4). NAM transcription factors in Oryza sativa have been described as important regulators of drought tolerance [63]. This may indicate a connection between these signaling pathways [71], possible co-regulation associated with sucrose content and cross-talks or signaling overlaps between sugar sensing, sugar mobilization and drought responses.
Among the genes more expressed in the immature internodes, we also found several genes similar to auxin, ethylene and giberellin-responsive TFs (Table 1). We found a second TF related to ARF6 (SCCCLR1024F10.g) and four AUXIN RESPONSE PROTEINS (SCCCRZ1001G10.g, SCVPLR2005H03.g, SCJFRZ2009F04.g, SCJLLR1 054C09.g) more expressed in immature internodes. Signaling by auxins during culm development was also pointed out by the altered expression of two nitrilase genes (SCEQRT1028H06.g and SCRFLR1012D12.g) with a putative role in this hormone's biosynthesis, an auxin efflux carrier (SCCCAM2004G02.g) and a AUXIN REPRESSED PROTEIN (SCCCLR2002F08.g) which is upregulated in mature internodes. One of the nitrilases (SCEQRT1028H06.g) was induced after 72h of drought [31] and its expression level was confirmed by qRT-PCR (Figure 4). Another drought-induced nitrilase (SCCCCL6002B05.g) was found more expressed in high Brix plants. This gene is highly similar to the maize $\mathrm{ZmNIT2}$ gene, which converts indole-3-acetonitrile to indole-3-acetic acid [72]. Overall, differential expression of auxin signaling genes during internode development and/or association with sucrose content was observed in twenty different biological samples.

Ethylene was observed as a putative modulator of this process (Table 1). One EIL was found less expressed in high Brix plants (SCCCRZ1004H12.g) and two were less expressed in mature internodes (SCBGFL4052C11.g and SCCCRZ1004H12.g). Besides, one ACC oxidase (SCVPLR2012A10.g) was found to be more expressed in high Brix plants and less expressed in mature internodes.

Jasmonic Acid biosynthesis also seems to have a relevant role in culm development since several enzymes envolved in methyl jasmonate biosynthesis were found to be more expressed in immature internodes, two lipoxygenases (SCCCRT1001E01.g and SCJFRT1007H07.g) and an Omega-6 fatty acid desaturase (SCCCLR1C03G01.g) (Table 1).

\section{Cell wall biosynthesis}

There were several genes with a putative function in cell wall metabolism that were among the differentially expressed genes, such as the expansins SCQGRT1040G03.g and SCCCLR2C02A05.g (Table 1). Similar genes were found to be expressed in two-day-old rice seedlings, a stage where rapid cell elongation occurs accompanied by cell division [73]. The authors believe EXP activity may be required for cell expansion. Expansins may act in the relaxation of the cell wall, possibly by breaking the bonds between cellulose microfibrils and matrix polysaccharides [74,75] allowing for cell expansion. Our data indicates that, in sugarcane, a gene similar 
to EXPA23 (SCQGRT1040G03.g) is more expressed in 7month old high Brix plants as compared to low-Brix plants, and the EXPA11 (SCCCLR2C02A05.g) in turn, is more expressed in low Brix plants (after 11 months of planting) (Table 1). As mentioned above, we have evidence that auxin signaling is highly active in immature internodes. Auxin signaling is associated with plant cell expansion [76], which may be an additional evidence that the high Brix plants selected have cell expansion alterations that might confer higher sucrose accumulation capacity. These observations are corroborated by the identification of a XYLOGLUCAN ENDO-B-1,4 GLUCANASE $(X T H)$ (SCBFLR1039B05.g) that is more expressed in immature internodes (Table 1). XTHs can hydrolyse xyloglucans, major components of plant cell walls, and transglycosylate residues into growing xyloglucan chains, that may be important during tissue expansion [77]. Our data is in agreement with previous findings from Casu and colleagues [12] that identified five XTHs and four $\beta$ expansins less expressed in mature internodes, as well as two caffeoyl-CoA O-methyltransferases induced in mature internodes.

We found five genes of the lignin biosynthesis pathway associated with sucrose content (Table 1). The first step in lignin biosynthesis in plants is the deamination of L-phenylalanine by Phenylalanine Ammonia-Lyase (PAL) to cinnamic Acid. PAL is the first enzyme of the phenylpropanoid pathway [78]. It converts L-phenylalanine into trans-cinnamic acid ( $t$-CA), which is further transformed in plants into many phenylpropanoid compounds, such as lignins, antioxidants, anthocyanins and flavonoid nodulation factors. We found three PAL genes associated with sucrose content and more expressed in immature internodes (SCCCLR1048D07.g, SCEQRT1024E12.g and SCSGAM1094D05.g). SCEQRT1024E12.g was induced after ABA treatment and repressed after 72 and $120 \mathrm{~h}$ drought stress. The second step in lignin biosynthesis is catalyzed by a cinnamate 4-hydroxylase (C4H) [79]. We found one SAS less expressed in high Brix similar to a $\mathrm{C} 4 \mathrm{H}$ (SCSGFL4193B05.g). Down the pathway p-Coumaroyl is transformed into Caffeoyl CoA by a p-coumaroyl shikimate 3'-hydroxylase $(\mathrm{C} 3 \mathrm{H})$. One SAS similar to a $\mathrm{C} 3 \mathrm{H}$ (SCACSB1037A07.g) was found less expressed in high Brix plants. We also observed a FERULATE 5-HYDROXYLASE (F5H) (SCEZHR1087F06.g) and a CAFFEIC ACID 3O-METHYLTRANSFERASE (COMT) (SCRFLR1012F12.g) more expressed in mature internodes. F5H was less expressed in high Brix while COMT was induced (Table 1 ). While all the above mentioned genes may have a role in cell wall metabolism, it is important to note that transcinnamic acid can also be converted into salicylic acid and anthocyanins [80] and, until the activity of these enzymes is verified, the data can only indicate a putative alteration in cell wall biosynthesis and modification in the accumulation of sucrose in culms.

Cell wall biosynthesis can reduce sucrose accumulation since carbon fluxes directed to plant growth and cell wall expansion may alter carbon partitioning into sucrose. It is also possible that sucrose accumulation may trigger increased lignification. One of the PAL enzymes was induced by sucrose treatment up to 14-fold indicating that this enzyme is highly responsive to sucrose. An induction of a COMT gene has already been described during culm maturation [12] but this is the first report implicating a $\mathrm{PAL}, \mathrm{C} 4 \mathrm{H}, \mathrm{C} 3 \mathrm{H}, \mathrm{F} 5 \mathrm{H}$ and COMT in sucrose content. It is possible that some of the genotypes analyzed also differ in biomass content and a continued agronomic evaluation is necessary to assess how gene expression in the selected genotypes is related to other characteristics, such as cell wall composition, growth rates, internode size and width, number of internodes and drought tolerance, for instance. Many parameters besides Brix may differ among the genotypes and have not yet been evaluated. It is possible also that the high Brix genotypes may be more amenable for acid and enzymatic hydrolysis and cellulosic ethanol production. Silencing of lignin biosynthesis genes has been shown to benefit sugar release for lignocellulosic biomass fermentation [81]; it will be thus interesting to test if altered biomass has been selected for during the breeding process. At any rate, the alteration of these cell wall biosynthesis genes in association to Brix content is an interesting indication of a correlation between these processes.

\section{A relationship between high sugar content and sugar signaling}

We showed that a set of genes associated with sucrose content is also early sugar-responsive. Since most of these genes are related to signal transduction (kinases, phosphatases, transcription factors, hormone synthesis) they are likely to constitute upstream components of the sugar regulatory cascade. These findings raise the interesting possibility that sugar signaling may somehow influence sugar accumulation capacity in sugarcane. How these genes may influence sucrose accumulation is an open question. Interestingly, between sucrose/glucose-treated young seedlings and high Brix genotypes, contrasting expression patterns were found for 15 genes, while the remaining 9 genes presented similar regulatory trends (Table 1 and data not shown). This latter set of genes may be related to higher sugar fluxes and/or higher sugar sensitivity in high Brix genotypes. Opposite regulatory patterns between young seedlings and internodes of high Brix 
genotypes are more difficult to explain, but could reflect differential developmental-dependent controls. A comparative analysis with Arabidopsis showed that among the twenty-four sugarcane genes tested, five Arabidopsis-sugarcane probable groups of orthologues and two pairs of Arabidopsis-sugarcane close homologues (sister clades) were apparently regulated similarly by sugars in seedlings (see Additional file 4). Orthologous genes of the signal transduction-class, such as those encoding transcription factors or kinases with conserved regulatory features, are likely to represent important players in the sugar signal transduction pathways and this can now be tested. Within this framework, it should also be interesting to further analyze the integration/interaction of the Arabidopsis CUC1/NACtype transcription factor (At3g1550), which controls shoot apical meristem formation [82] in the sugar regulatory network.

\section{Data validation across genotypes}

To confirm gene expression and evaluate transcript levels we performed qRT-PCR reactions for forty-two genes. With a probability value higher than 0.95 we observed that $80 \%$ of the gene expression data obtained using cDNA microarrays were compatible with the qRT-PCR data.

Validation of developmental regulation was elucidative of differences among high Brix and low Brix populations. ScCIPK-21 for instance, a gene more expressed in high Brix and in mature internodes, was found to be much more induced during culm development in the high Brix plants, what may be an indicative that induction of this gene may lead to higher sucrose levels. A category that was consistently more expressed in immature internodes and high Brix and that has been seen to be responsive to drought in other plants is the aquaporin family of proteins. We wanted to verify if genes of this family could be useful expression markers of sucrose content. Five aquaporins, from both the MIP and PIP sub-families (SCCC RZ1002E08.g, SCCCST3001H12.g, SCEQRT2100B02.g, SCCCLR1024C03.g, and SCCCRZ1001F02.g) were regulated during culm development and two of them found to be associated with high Brix (SCCCST3001H12.g and SCEQRT2100B02.g) in population 2 (Table 1). This large family of proteins is primarily involved in the regulation of water movement between cells and cell compartments, although many of them also facilitate the passage of small solutes $[83,84]$. The accumulation of sucrose in such high concentrations as seen in sugarcane cells certainly represents an osmotic challenge that demands efficient control of solute compartmentalization and water transport out of the vacuoles. As key players in the equilibration of water potentials via regulation of membrane permeability, aquaporins may have a fundamental role in the proc- ess of sugar storage in sugarcane vacuoles. It has been observed in Arabidopsis that loss of the aquaporin TIP1.1 severely affects carbohydrate metabolism and transport [85], and the authors postulate that this aquaporin could be involved in a vesicle-based routing of carbohydrates towards the central vacuole. In our study, expression of one aquaporin correlated to lower sucrose content in both populations analyzed. Since differential expression was determined in pools of seven or eight individuals we decided to verify how many of the genotypes in those pools presented the observed expression patterns. Expression data was obtained using qRT-PCR for twelve of the sixteen extreme individuals of Population 1 (Figure 5). We calculated the average expression levels across all twelve genotypes for the Aquaporin gene (SCCCRZ1002E08.g) and observed that the gene was less expressed in all high Brix genotypes and more expressed in half of the low Brix genotypes. This is a strong indicative that low expression of this gene has been segregated and selected by the breeding process and is strongly associated with high sucrose content. To verify if this would be the case for other differentially expressed genes we evaluated the expression profiles of eleven genes in the twelve extreme genotypes of Population 1. For some genes, such as the HLH TF (SCCCRZ1001H05.g), expression was consistently lower than average in all low Brix genotypes, but found to be higher in only two of the high Brix genotypes (Figure 5). In this case, the two genotypes had almost 10,000 fold increased expression for the genes, which may account for the differential expression observed in the pool used for cDNA microarray analysis. This is an extreme case and, in general, most of the data shows around $50 \%$ of validation in the individual genotype validations.

\section{Conclusion}

Gene expression analysis of sugarcane populations contrasting for sucrose content indicated a possible overlap of sugar, drought and cell wall metabolism processes and suggested signaling and transcriptional regulators that might be useful as molecular markers in breeding programs or as primary targets in a sugarcane improvement program based on transgenic plants. This work is a first survey on gene expression related to sucrose content and some similarities point to conservation between monocot and dicot sucrose responses. This observation can help to point the important players in the sugar signal transduction pathways. Due to the diversity of roles described for the identified genes, additional experiments will be necessary to elucidate their possible roles in the sugarcane sucrose accumulation process. Our group is currently generating transgenic plants with modified expression levels for these genes to confirm the hypothesis raised for their function. 


\section{Methods \\ Biological samples}

Population 1 was derived from two intra-specific polycrosses, one among 21 Saccharum officinarum genotypes (Caiana Fita, IK76108, Lahaina, MZ151, MZ151 roxa, Sabura, Salangor, Sinimbu, NG213, Fiji 47, Hinahina 18, Manjri Red, Muntok Java, NG77142, Soff 8268, SS601, Sylva, NG2880, Vae Vae Ula, IJ76315 and IN8425) and the other combining 13 Saccharum spontaneum genotypes (IN8458, IN8488, Krakatau, SES 147b, US56158, US7440, US851008, UM721, UM691, SES 194, IK7686, US56193 and US571723). The individuals of these polycrosses were crossed amongst themselves and for each generation, 500 individuals were sampled for soluble solids (Brix degree). The extreme segregants of the F3 hybrid individuals were planted in a field in single rows of $5 \mathrm{~m}$ using standard sugarcane cultivation practices. Tissue samples were collected in March of the following year, when plants were 10 months old. The Brix degree content of the $4^{\text {th }}-5^{\text {th }}$ internodes of each sugarcane stalk was measured with a portable refractometer (N1 model, ATAGO, Japan). Additional file 1 lists Brix measurements for the extreme individuals of both populations [33] and the corresponding sucrose concentration. The average Brix value for high sugar individuals was $18.10+/-1.44$ and for low sugar individuals was $6.70+/-0.96$ for Population 1 . Sucrose content was $9.2 \%$ in high Brix individuals and $1.1 \%$ in low Brix individuals for this population. Sugars were determined as described [86,87].

Population 2 was derived from a cross between two commercial varieties (SP80-180 × SP80-4966). Five hundred sugarcane F1 plants were field-grown. Seven plants with extreme Brix values were selected. Population 2 was less contrasting than Population 1, with an average high Brix of $18.47+/-1.41$ and average low Brix of 13.65 +/- 1.27.

Sucrose accumulating tissues (sink tissues, herein internodes) were collected from field grown plants. We have previously determined using Pair-wise Pearson correlation calculations a high correlation of gene expression between individuals collected at the same time or within a short interval of time ( 0.84 to 0.88$)$, and a lower correlation between individuals collected in different years (0.61 to 0.64) [88]. Mature (In9), intermediate (In5) and immature internodes (In1) were then collected from four selected plants of each genotype at 7, 10 and 11 months after planting. Tissue collected from the four plants was pooled, therefore each biological sample corresponds to a certain tissue derived from four plants, and the gene expression data reflects the average expression of the pooled plant tissue. A total of 132 biological samples were selected for gene expression studies from both popula- tions. RNA was extracted from tissues of individuals or pools of eight individuals as described [31].

The cultivar SP90-1638 (Internal Technical Report, CTC, 2002), sensitive to drought, was used for the water deprivation experiments. The experiments were previously described [31]. Briefly, plants were transferred to pots containing moist sand under greenhouse conditions. Regular watering was maintained for 90 days, being suppressed after this period for the experimental group. Aerial parts of six plants for each experimental point were collected 24, 72 and $120 \mathrm{~h}$ after the onset of drought for the control and experimental groups.

For ABA treatment, plants derived from shoot apex of 2month-old sugarcane plants were in vitro cultivated for approximately three months in a growth chamber as described [31]. ABA (Sigma Chem. Co) was added to the culture medium to a final concentration of a $100 \mu \mathrm{mol} . \mathrm{L}$ ${ }^{-1}$ whereas control plants were treated with distilled water. Leaves were collected after $0.5 \mathrm{~h}, 1 \mathrm{~h}, 6 \mathrm{~h}$ and $12 \mathrm{~h}$ of exposure to ABA. Six plantlets were sampled for each time point.

For sucrose treatment, seeds obtained from a crossing between SP891046 and IAC912195 varieties were imbibed in water, incubated for $10 \mathrm{~min}$ at $52^{\circ} \mathrm{C}$ to open the panicle and sterilized by a 5-min treatment in $70 \%$ ethanol followed by 20 -min in $2.5 \%$ sodium hypoclorite. Seeds were then washed 5 times in sterile water and then transferred to a Musharige and Skoog half-strength solid growing media [89] containing $0.5 \%$ of sucrose. Plates were incubated in continuous light for 12 days at $28^{\circ} \mathrm{C}$. Subsequently,_seedlings were transferred to liquid MS/2 growth medium without any sugar and further grown for $24 \mathrm{~h}$ under weak agitation (60 rpm) and constant light before being treated with $3 \%$ sucrose or $3 \%$ glucose or $3 \%$ mannitol (stock solution of $30 \%$ in water) or just with water as control for $4 \mathrm{~h}$. RNA was extracted using Concert ${ }^{\circledR}$ (Invitrogen, USA) according to the manufacturer's recommendations.

\section{Gene expression data}

cDNA microarray experiments were conducted and data extracted as described previously [31]. SUCEST SAS consensus sequences can be found at http://sucest fun.iq.usp.br/sucestfun/database/Sugarcane-Clustering fasta. The corresponding Sugarcane Gene Index contigs http://compbio.dfci.harvard.edu/tgi/plant.html can be searched at http://sucestfun.iq.usp.br/cgi-bin/pub sucest/ clustering comparison.cgi and downloaded at http:// sucest-fun.org/pub/brix/data/SAS vs SGI.blastn.csv and http://sucest-fun.org/pub/brix/data/SGI vs SAS.blastn 
.csv. The designed microarray contains 1830 genes which yielded 1545 good-quality PCR fragments. Reverse transcription, labeling and hybridizations were done using the reagents provided with the CyScribe Post-Labeling kit (GE Healthcare) or SuperScript ${ }^{\mathrm{Tm}}$ Plus Indirect cDNA Labeling System (Invitrogen, USA). The microarrays were scanned according to the manufacturer's instructions using the Generation III System (Molecular Dynamics). Hybridizations were carried out as described [33].

Two technical replicates were obtained for each microarray experiment. Data were collected using the ArrayVision (Imaging Research Inc.) software. The fluorescence ratios were normalized in the MxS space, where $\mathrm{M}$ is the base 2 logarithm of the intensities ratio and $\mathrm{S}$ is the base 2 logarithm of the average intensity of each spot. The $M$ values were normalized to account for systematic errors using the LOWESS fitting. The identification of differentially expressed genes was performed using a local implementation of the Outliers Search method [31]. The SAS presenting more than $70 \%$ of its replicates outside fold-change cut-off curves were defined as differentially expressed. Raw data can be found at https://sucestfun.iq.usp.br/pub/ brix/index.html.

\section{Validation of microarray results by real-time PCR (qRT- PCR)}

Real-time PCR reactions were done essentially as described [31]. The ratio between the relative amounts of the target gene and the endogenous control gene in the qRT-PCR reactions was determined based on the $\mathrm{Ct}$ method [90] with modifications. The normalized expression level was calculated as $\mathrm{L}=2^{-\Delta \mathrm{Ct}}$ and $\Delta \mathrm{CT}=\mathrm{C}_{\mathrm{T}}$, target ${ }^{-}$ $\mathrm{C}_{\mathrm{T}}$, reference. $\mathrm{A}$ polyubiquitin (PUB) gene (SCCCST2001G02.g) was used as an endogenous reference in the qRT-PCR reactions of high Brix and low Brix samples after verification that its mRNA levels were similar in the populations and individual tissues. This PUB gene was also used for the sucrose-responsive gene expression validation. Drought samples were normalized using a GAPDH (CA254672.1 [91]), PUB (SCCCST2001G02.g) or Ubiquitin (SCCCLR1048F12.g) genes and ABA samples using a UBE2 (ubiquitin conjugating enzyme E2) (SCBGLR1002D06.g) or PUB gene (SCCCST2001G02.g).

To access the statistical significance of expression ratios, we assumed a log-normal model and calculated the probability $\mathrm{P}=\operatorname{Pr}$ (sample>reference) and $\mathrm{P}=\operatorname{Pr}($ sample $<$ reference) for up- and down-regulated genes, respectively. The expression profile was considered validated when $\mathrm{P} \geq$ 0.95 . For validation of gene expression differences among all different genotypes the probability value $\mathrm{P}$ of being greater or smaller than the average expression across all individuals was calculated depending on whether the con- dition was respectively up- or down-regulated according to the microarray data.

\section{Comparative sequence analysis}

Comparative analysis of sugarcane sugar-responsive genes was done by constructing phylogenetic trees containing the corresponding most similar plant sequences. A tblastx search [92] with the sugar-regulated SAS against a green plants protein data set including 365,187 proteins sequences obtained from several genomes (Arabidopsis thaliana, version 7.0 - http://www.arabidopsis.org; Populus trichocarpa, version 1.1 - http://genome.jgi-psf.org/ Poptr1 1/Poptr1 1.home.html; Glycine max, version 0.1 - http://www.phytozome.net/soybean.php; Oryza sativa, version 5.0 - http://www.tigr.org/tdb/e2k1/osa1/pseudo molecules/info.shtml; Sorghum bicolor, version 1.4 - http:/ Lgenome.jgi-psf.org/Sorbi1/Sorbi1.home.html; Selaginella moellendorffii, version 1.0 - http://genome.jgipsf.org/Selmo1/Selmo1.home.html; Physcomitrella patens patens, version 1.1 - http://genome.jgi-psf.org/Phypa1_1/ Phypa1 1.home.html; Volvox carteri, version 1.0 - http:// genome.jgi-psf.org/Volca1/Volca1.home.html;

Chlamydomonas reinhardtii, version 3.0 - http:// genome.jgi-psf.org/chlre3/chlre3.home.html; Ostreococcus lucimarinus, version 2.0 - http://genome.jgi-psf.org/ Ost9901 3/Ost9901 3.html; Ostreococcus tauri, version 2.0 - http:/genome.jgi-psf.org/Ostta4/Ostta4.home .html; Micromonas pusilla CCMP1545, version 2.0 - http:/ /genome.jgi-psf.org/MicpuC2/MicpuC2.home.html; Micromonas strain RCC299, version 2.0 - http://genome .jgi-psf.org/MicpuN2/MicpuN2.home.html) was performed. For each SAS, the first 40 best matches, or all matches obtained if this number were lower than 40 , were selected for further analysis. The conserved domains found among the 40 selected sequences were aligned using ClustalW [93] to produce ungapped alignments. The phylogenetic relationship of these aligned sequences was then constructed using the Neighbor-Joining method [94] using p-distance. All analysis were conducted in MEGA4 software [95]. This process allowed identifying the most probable orthologues sequences of the SAS. The Arabidopsis orthologues and the Arabidopsis more closely related homologues (usually one sister clade which may include at least two Arabidopsis sequences) were compared with the set of Arabidopsis genes regulated by glucose [30] and/or sucrose [34] using VennMaster 0.37 .3 http://www.informatik.uni-ulm.de/ni/staff/ HKestler/vennm/doc.html.

\section{Authors' contributions}

FSPT, FRR, AJW, CGL, MDLC and DB conducted cDNA microarray and qRT-PCR experiments. LEVDB conducted the phylogenetic analysis. ECU was responsible for sugarcane cultivation and germplasm sample collection. MYNJ, 
RZNV and RV were responsible for bioinformatic analysis and database development. MV, MM and GMS are group leaders, designed the experiments, analysed the data and had intelectual input in all activities listed above. All authors contributed to datamining, read the manuscript and approved it.

\section{Note}

Additional files can be found at http://sucest-fun.org/ pub/brix

Raw data has been uploaded to GEO Database (Series GSE14732)

\section{Additional material}

\section{Additional file 1}

Brix degree and sugar content of populations. Brix degree, sucrose, glucose and fructose were determined from 10-month old plants of Population 1 and 11-month old plants of Population 2. The measurements were made from juice extracted from the $9^{\text {th }}$ internode. Brix measurements of these populations have been previously described [33]

Click here for file

[http://www.biomedcentral.com/content/supplementary/14712164-10-120-S1.xls]

\section{Additional file 2}

SAS showing differential expression when high and low Brix plants were compared or when mature and immature internodes were compared using cDNA microarrays. The table also shows differential expression of the same SAS as seen in [31] for plants submitted to drought and $A B A$ treatment. The table lists a SAS whose expression was enriched or decreased as determined by the Outliers Search Method in two technical replicates for each biological sample. The expression ratio for each technical replicate is in brackets.

Click here for file

[http://www.biomedcentral.com/content/supplementary/1471-

2164-10-120-S2.xls]

\section{Additional file 3}

$P$ value of $q R T-P C R$. Genes associated with sucrose content, drought, $A B A$ and sugars were validated by qRT-PCR. The tables indicate all the genes evaluated and the values of $P$ for differential expression.

Click here for file

[http://www.biomedcentral.com/content/supplementary/14712164-10-120-S3.doc]

\section{Additional file 4}

Sugarcane and Arabidopsis orthologues similarly regulated by sucrose and glucose. Orthologies between Sugarcane and Arabidopsis were assigned using the Neighbor-Joining method [94]. The Arabidopsis orthologues were compared with the set of Arabidopsis genes regulated by glucose [30] and/or sucrose [34].

Click here for file

[http://www.biomedcentral.com/content/supplementary/14712164-10-120-S4.xls]

\section{Additional file 5}

Inferred phylogenetic relationships among tblastx hits using the sugarcane SAS as queries. The amino acid alignments were performed with ClustalX. The distances were obtained by p-distance and topography inferred with Neighbor-Joining (NJ) using only the aligned blocks (complete deletion). Analysis were conducted in MEGA4. The continuous blocks show regulation by sucrose and the pointed blocks show regulation by glucose (in both cases red for induction and green for repression). A SCRFLR2037F09.g (Calreticulin 2); B - SCEQRT1024E12.g (Phenylalanine ammonia-lyase); C - SCCCRZ1001G10.g (IAA16); D SCACLR2007G02.g and SCRFLR1034G06.g (canePKABA1-1 and canePKABA1-3); E - SCQGLR1085F11.g (Dehydrin). The sequences names correspond to those present in the protein data sets showed in Material \& Methods: AT - Arabidopsis thaliana; $\mathbf{G m}$ - Glycine max (soybean); jgi|Poptr1 - Populus trichocarpa; LOC Os - Oryza sativa (rice); $\boldsymbol{S} \boldsymbol{b}$-Sorghum bicolor (sorghum); jgi|Selmo1 - Selaginella moellendorffii; jgi|Phypa1_1 - Physcomitrella patens patens; jgi|MicpuC2 - Micromonas pusilla CCMP1545, jgi|MicpuN2 Micromonas strain RCC299; jgi|Volca1 - Volvox carteri; jgi|Chlre3 - Chlamydomonas reinhardtii.

Click here for file

[http://www.biomedcentral.com/content/supplementary/14712164-10-120-S5.pdf]

\section{Acknowledgements}

We thank Dr. Carlos Hotta and Dr. Michael Lawton for a critical review of the manuscript. We are indebted to Maria Cristina Falco, Sabrina Moutinho Chabregas, Paulo Gouvêa e William Burniquist for their technical support in the development of this work. This work was funded by Fundação de Àmparo à Pesquisa do Estado de São Paulo (FAPESP). G. M. S., M. M. are recipients of productivity fellowships from CNPq.

\section{References}

I. Daniels J, Roach BT: Taxonomy and evolution in sugarcane. In Sugarcane improvement through breeding Edited by: Heinz D. Amsterdam: Elsevier Press; 1987:7-84.

2. Daniels J, Daniels C: Geographical, historical and cultural aspect of the origin of the Indian and Chinese sugarcanes $S$. barberi and S. sinense. Sugarcane Breeding newsletter 1975, 36:4-23.

3. Roach BT: Nobilisation of sugarcane. Proc Int Soc Sugar Cane Technol 1972, 14:206-216.

4. Arceneaux G: Cultivated sugarcanes of the world and their botanical derivation. Proc Int Soc Sugar Cane Technol 1967, I 2:844-854.

5. Price S: Interspecific hybridization in sugarcane breeding. Proc Int Soc Sugar Cane Technol 1965, I 2:1021-1026.

6. Lingle SE: Seasonal internode development and sugar metabolism in sugarcane. Crop Science 1997, 37(4):844-854.

7. Menossi M, Silva-Filho MC, Vincentz M, Van-Sluys MA, Souza GM: Sugarcane Functional Genomics: gene discovery for agronomic trait development. Int J Plant Genomics 2008: I- II.

8. Carson DL, Botha FC: Genes expressed in sugarcane maturing internodal tissue. Plant cell reports 2002, 20:1075-108I.

9. Carson DL, Huckett BI, Botha FC: Sugarcane ESTs differentially expressed in immature and maturing internodal tissue. Plant Sci 2002, 162:289-300.

10. Casu RE, Grof CP, Rae AL, McIntyre CL, Dimmock CM, Manners JM: Identification of a novel sugar transporter homologue strongly expressed in maturing stem vascular tissues of sugarcane by expressed sequence tag and microarray analysis. Plant molecular biology 2003, 52(2):37|-386. 
11. Casu RE, Dimmock CM, Chapman SC, Grof CP, Mclntyre CL, Bonnett GD, Manners JM: Identification of differentially expressed transcripts from maturing stem of sugarcane by in silico analysis of stem expressed sequence tags and gene expression profiling. Plant Mol Biol 2004, 54(4):503-5 I7.

12. Casu RE, Jarmey JM, Bonnett GD, Manners JM: Identification of transcripts associated with cell wall metabolism and development in the stem of sugarcane by Affymetrix GeneChip Sugarcane Genome Array expression profiling. Functional \& integrative genomics 2007, 7(2): 153-167.

13. Riera M, Valon C, Fenzi F, Giraudat J, Leung J: The genetics of adaptive responses to drought stress: abscisic acid-dependent and abscisic acid-independent signalling components. Physiologia Plantarum 2005, I 23: I I I- II 9.

14. Bray EA: Molecular Responses to Water Deficit. Plant Physiol 1993, 103(4): 1035-1040.

15. Bohnert H], Nelson DE, Jensen RG: Adaptations to Environmental Stresses. The Plant cell 1995, 7(7): 1099-IIII.

16. Ingram J, Bartels D: The Molecular Basis of Dehydration Tolerance in Plants. Annu Rev Plant Physiol Plant Mol Biol 1996, 47:377-403.

17. Seki M, Narusaka M, Abe H, Kasuga M, Yamaguchi-Shinozaki K, Carninci $P$, Hayashizaki $Y$, Shinozaki K: Monitoring the expression pattern of 1300 Arabidopsis genes under drought and cold stresses by using a full-length cDNA microarray. The Plant cell 200I, I3(I):6I-72.

18. Oono Y, Seki M, Nanjo T, Narusaka M, Fujita M, Satoh R, Satou M, Sakurai T, Ishida J, Akiyama K, et al.: Monitoring expression profiles of Arabidopsis gene expression during rehydration process after dehydration using ca 7000 full-length cDNA microarray. Plant / 2003, 34(6):868-887.

19. Yamaguchi-Shinozaki K, Shinozaki K: Transcriptional regulatory networks in cellular responses and tolerance to dehydration and cold stresses. Annual review of plant biology 2006, 57:78I-803.

20. Gupta $A K$, Kaur N: Sugar signalling and gene expression in relation to carbohydrate metabolism under abiotic stresses in plants. J Biosci 2005, 30(5):76I-776.

21. Smeekens S: Sugar induced signal transduction in plants. Annu Rev Plant Physiol Plant Mol Biol 2000, 5 I:49-8I.

22. Rolland F, Winderickx J, Thevelein JM: Glucose-sensing and -signalling mechanisms in yeast. FEMS yeast research 2002, 2(2): $|83-20|$.

23. Koch K: Sucrose metabolism: regulatory mechanisms and pivotal roles in sugar sensing and plant development. Current opinion in plant biology 2004, 7:235-246.

24. Gibson SI: Control of Plant development and gene expression by sugar signaling. Current opinion in plant biology 2005, 8:93-102.

25. Rolland F, Baena-Gonzalez E, Sheen J: Sugar sensing and signaling in plants: conserved and novel mechanisms. Annual review of plant biology 2006, 57:675-709.

26. Moore B, Zhou L, Rolland F, Hall Q, Cheng W-H, Liu Y-X, Hwang I, Jones T, Sheen J: Role of the Arabidopsis glucose sensor HXK I in nutrient, light and hormonal signaling. Science 2003, 3000:332-336

27. Halford NG, Paul MJ: Carbon metabolite sensing and signalling. Plant biotechnology journal 2003, I(6):38I-398.

28. Zhou L, Jang J-C, Jones TL, Sheen J: Glucose and ethylene signal transduction crosstalk revealed by an Arabidopsis glucoseinsensitive mutant. Proc Nat Acad SciUSA 1998, 95:10294-10299.

29. Cheng WH, Endo A, Zhou L, Penney J, Chen HC, Arroyo A, Leon P, Nambara E, Asami T, Seo M, et al.: A unique short-chain dehydrogenase/reductase in Arabidopsis glucose signaling and abscisic acid biosyntesis and functions. Plant Cell 2002, I 4(I I):2723-2743.

30. Li Y, Lee KK, Walsh S, Smith C, Hadingham S, Sorefan K, Cawley G, Bevan MW: Establishing glucose- and ABA-regulated transcription networks in Arabidopsis by microarray analysis and promoter classification using a Relevance Vector Machine. Genome Res 2006, 16:414-427.

3I. Rocha FR, Papini-Terzi FS, Nishiyama MY Jr, Vencio RZ, Vicentini R, Duarte RD, de Rosa VE Jr, Vinagre F, Barsalobres C, Medeiros AH, et al.: Signal transduction-related responses to phytohormones and environmental challenges in sugarcane. BMC Genomics 2007, 8:71.

32. Vettore AL, da Silva FR, Kemper EL, Souza GM, da Silva AM, Ferro MI, Henrique-Silva F, Giglioti EA, Lemos MV, Coutinho LL, et al.: Analy- sis and functional annotation of an expressed sequence tag collection for tropical crop sugarcane. Genome Res 2003, I 3( I 2):2725-2735.

33. Papini-Terzi FS, Felix JM, Rocha FR, Waclawovsky AJ, Ulian EC, Chabregas S, Falco MC, Nishiyama-Jr MY, Vêncio RZN, Vicentini R, et al: The SUCEST-FUN Project: identifying genes that regulate sucrose content in sugarcane plants. Proc Int Soc Sugar Cane Technol 2007, 26(6):25-29.

34. Osuna D, Usadel B, Morcuende R, Gibon Y, Bläsing OE, Höhne M, Günter M, Kamlage B, Trethewey R, Scheible WR, et al.: Temporal responses of transcripts, enzyme activities and metabolites after adding sucrose to carbon-deprived Arabidopsis seedlings. Plant $J$ 2007, 49(3):463-49|

35. Moore PH: Temporal and spatial regulation of sucrose accumulation in the sugarcane stem. Austr J Plant Physiol 1995, 22:66I-679.

36. McCormick AJ, Cramer MD, Watt DA: Changes in photosynthetic rates and gene expression of leaves during a sourcesink perturbation in sugarcane. Annals of Botany 2008, 101:89-102

37. Ming R, Liu SC, Moore PH, Irvine JE, Paterson AH: QTL analysis in a complex autopolyploid: genetic control of sugar content in sugarcane. Genome Res 200 I, I I ( 2 2):2075-2084.

38. Casu R, Dimmock C, Thomas M, Bower N, Knight D: Genetic and expression profiling in sugarcane. Proc Int Soc Sugar Cane Technol 200I, 24:542-546.

39. Watt D, McCormics A, Govender C, Crame M, Huckett B: Increasing the utility of genomics in unraveling sucrose accumulation. Field Crop Res 2005, 92: I49-I58.

40. Jansen RC, Nap JP: Genetical genomics: the added value from segregation. Trends Genet 200I, I7(7):388-39I.

41. Ehness R, Ecker M, Godt D, Roitsch T: Glucose and stress independently regulate source/sink relations and defense mechanisms via signal transduction pathways involving protein phosphorylation. The Plant cell 1997, 9: I825-I84I.

42. Woods A, Munday MR, Scott J, Yang X, Carlson M, Carling D: Yeast SNFI is functionally related to mammalian AMP-activated protein kinase and regulates acetyl-CoA carboxylase in vivo. The Journal of biological chemistry 1994, 269(30): 19509-19515.

43. Halford NG, Hardie DG: SNFI-related protein kinases: global regulators of carbon metabolism in plants? Plant Mol Biol 1998 , 37(5):735-748.

44. Barker JH, Slocombe SP, Ball KL, Hardie DG, Shewry PR, Halford NG: Evidence that barley 3-hydroxy-3-methylglutaryl-coenzyme a reductase kinase is a member of the sucrose nonfermenting-I-related protein kinase family. Plant Physiol 1996, I |2(3): | |4|-|| 49 .

45. Sugden C, Donaghy PG, Halford NG, Hardie DG: Two SNFIrelated protein kinases from spinach leaf phosphorylate and inactivate 3-hydroxy-3-methylglutaryl-coenzyme $\mathbf{A}$ reductase, nitrate reductase, and sucrose phosphate synthase in vitro. Plant Physiol 1999, I 20 (I):257-274.

46. Douglas P, Pigaglio E, Ferrer A, Halfords NG, MacKintosh C: Three spinach leaf nitrate reductase-3-hydroxy-3-methylglutarylCoA reductase kinases that are required by reversible phosphorylation and/or Ca2+ ions. The Biochemical journal 1997, 325(Pt I): 10I-109.

47. Toroser D, Athwal GS, Huber SC: Site-specific regulatory interaction between spinach leaf sucrose-phosphate synthase and 14-3-3 proteins. FEBS letters 1998, 435(1): I10-114.

48. Sanders D, Pelloux J, Brownlee C, Harper JF: Calcium at the crossroads of signaling. The Plant cell 2002, I 4(Suppl):S40 I-4I7.

49. Boudsocq M, Lauriere C: Osmotic signaling in plants: multiple pathways mediated by emerging kinase families. Plant Physiol 2005, I38(3): II85-II94.

50. Huber SC, Huber JL, Liao PC, Gage DA, McMichael RW Jr, Chourey PS, Hannah LC, Koch K: Phosphorylation of serine-I 5 of maize leaf sucrose synthase. Occurrence in vivo and possible regulatory significance. Plant Physiol 1996, I I 2(2):793-802.

51. Zhang XQ, Lund AA, Sarath G, Cerny RL, Roberts DM, Chollet R: Soybean nodule sucrose synthase (nodulin-100): further analysis of its phosphorylation using recombinant and authentic root-nodule enzymes. Archives of biochemistry and biophysics 1999, 37I(I):70-82.

52. Hardin SC, Tang GQ, Scholz A, Holtgraewe D, Winter H, Huber SC: Phosphorylation of sucrose synthase at serine 170: occur- 
rence and possible role as a signal for proteolysis. Plant J 2003, 35(5):588-603.

53. Hardin SC, Winter H, Huber SC: Phosphorylation of the amino terminus of maize sucrose synthase in relation to membrane association and enzyme activity. Plant Physiol 2004, I34(4): | 427- I 438.

54. Hardin SC, Huber SC: Proteasome activity and the post-translational control of sucrose synthase stability in maize leaves. Plant Physiol Biochem 2004, 42(3): 197-208.

55. Zrenner R, Salanoubat M, Willmitzer L, Sonnewald U: Evidence of the crucial role of sucrose synthase for sink strength using transgenic potato plants (Solanum tuberosum L.). Plant J 1995, 7(1):97-107.

56. Hanggi E, Fleming AJ: Sucrose synthase expression pattern in young maize leaves: implications for phloem transport. Planta 200I, 21 4(2):326-329.

57. McMichael RW Jr, Bachmann M, Huber SC: Spinach Leaf SucrosePhosphate Synthase and Nitrate Reductase Are Phosphorylated/Inactivated by Multiple Protein Kinases in Vitro. Plant Physiol 1995, 108(3): 1077-1082.

58. Pagnussat GC, Fiol DF, Salerno GL: A CDPK type protein kinase is involved in rice SPS light modulation. Physiol Plant 2002 I I5(2): 183-189.

59. Merlot S, Gosti F, Guerrier D, Vavasseur A, Giraudat J: The ABII and $A B \mid 2$ protein phosphatases $2 C$ act in a negative feedback regulatory loop of the abscisic acid signalling pathway. Plant 200I, 25(3):295-303.

60. Tahtiharju S, Palva T: Antisense inhibition of protein phosphatase 2C accelerates cold acclimation in Arabidopsis thaliana. Plant J 200I, 26(4):46 I-470.

61. Nambara E, Marion-Poll A: Abscisic acid biosynthesis and catabolism. Annual review of plant biology 2005, 56:165-185.

62. Xiong L, Schumaker KS, Zhu JK: Cell signaling during cold, drought, and salt stress. The Plant cell 2002, I4(Suppl):SI65-183.

63. Hu H, Dai M, Yao J, Xiao B, Li X, Zhang Q, Xiong L: Overexpressing a NAM, ATAF, and CUC (NAC) transcription factor enhances drought resistance and salt tolerance in rice. Proc Natl Acad Sci USA 2006, I 03(35): 12987-I 2992.

64. Lee SC, Lee MY, Kim SJ, Jun SH, An G, Kim SR: Characterization of an abiotic stress-inducible dehydrin gene, OsDhn I, in rice (Oryza sativa L.). Mol Cells 2005, I9(2):2।2-2।8.

65. Tabaei-Aghdaei SR, Pearce RS, Harrison P: Sugars regulate coldinduced gene expression and freezing-tolerance in barley cell cultures. J Exp Bot 2003, 54(387): I565-I575.

66. Sakuma Y, Maruyama K, Osakabe Y, Oin F, Seki M, Shinozaki K, Yamaguchi-Shinozaki K: Functional analysis of an Arabidopsis transcription factor, DREB2A, involved in drought-responsive gene expression. The Plant cell 2006, 18(5): 1292-1309.

67. Sakuma Y, Maruyama K, Qin F, Osakabe Y, Shinozaki K, YamaguchiShinozaki K: Dual function of an Arabidopsis transcription factor DREB2A in water-stress-responsive and heat-stressresponsive gene expression. Proc Natl Acad Sci USA 2006, I 03(49): | 8822-I8827.

68. Yilmaz A, Nishiyama MYJ, Fuentes BG, Souza GM, Janies D, Gray J, Grotewold E: GRASSIUS: A Platform for Comparative Regulatory Genomics across the Grasses. Plant Physiol 2009, I49(I): $17 \mid-180$

69. Vollbrecht E, Veit B, Sinha N, Hake S: The developmental gene Knotted-I is a member of a maize homeobox gene family. Nature 1991, 350(36 I5):24|-243.

70. Ludwig SR, Habera LF, Dellaporta SL, Wessler SR: Lc, a member of the maize $R$ gene family responsible for tissue-specific anthocyanin production, encodes a protein similar to transcriptional activators and contains the myc-homology region. Proc Natl Acad Sci USA 1989, 86( 18):7092-7096.

71. Aoki K, Ogata Y, Shibata D: Approaches for Extracting Practical Information from Gene Co-expression Networks in Plant Biology. Plant Cell Physiol 2007, 48(3):38I-390.

72. Park W], Kriechbaumer V, Möller A, Piotrowski M, Meeley RB, A G Glawischnig E: The Nitrilase ZmNIT2 converts indole-3-acetonitrile to indole-3-acetic acid. Plant Physiol 2003, I33(2):794-802.

73. Shin JH, Jeong DH, Park MC, An G: Characterization and transcriptional expression of the alpha-expansin gene family in rice. Mol Cells 2005, 20(2):210-218.
74. Cosgrove DJ, Li LC, Cho HT, Hoffmann-Benning S, Moore RC, Blecker D: The growing world of expansins. Plant Cell Physiol 2002, 43( I 2): | 436-| 444

75. McQueen-Mason S, Cosgrove DJ: Disruption of hydrogen bonding between plant cell wall polymers by proteins that induce wall extension. Proc Natl Acad Sci USA 1994, 9 I (14):6574-6578.

76. Mockaitis K, Estelle M: Integrating transcriptional controls for plant cell expansion. Genome Biol 2004, 5(I I):245.

77. Farrokhi N, Burton RA, Brownfield L, Hrmova M, Wilson SM, Bacic A, Fincher GB: Plant cell wall biosynthesis: genetic, biochemical and functional genomics approaches to the identification of key genes. Plant biotechnology journal 2006, 4(2): I45-167.

78. MacDonald MJ, D'Cunha GB: A modern view of phenylalanine ammonia lyase. Biochem Cell Biol 2007, 85(3):273-282.

79. Boudet AM, Kajita S, Grima-Pettenati J, Goffner D: Lignins and lignocellulosics: a better control of synthesis for new and improved uses. Trends Plant Sci 2003, 8( I 2):576-58 I.

80. Lee HI, León J, Raskin I: Biosynthesis and metabolism of salicylic acid. Proc Natl Acad Sci USA 1995, 92( 1 0):4076-4079.

81. Chen F, Dixon RA: Lignin modification improves fermentable sugar yields for biofuel production. Nature biotechnology 2007, 25:759-76।.

82. Takada S, Hibara K Ishida T, Tasaka M: The CUP-SHAPED COTYLEDONI gene of Arabidopsis regulates shoot apical meristem formation. Development 200 I, I 28(7): I I 27-I I 35.

83. Maurel C, Chrispeels MJ: Aquaporins. A Molecular Entry into Plant Water Relations. Plant Physiol 200I, 125:I35-138.

84. Chaumont F, Moshelion M, Daniels MJ: Regulation of plant aquaporin activity. Biol Cell 2005, 97( I 0):749-764

85. Ma S, Quist TM, Ulanov A, Joly R, Bohnert HJ: Loss of TIPI;I aquaporin in Arabidopsis leads to cell and plant death. Plant J 2004, 40(6):845-859.

86. DiCesare JL: The analysis of carbohydrates on high eficiency columns using an aqueous fase. Chromatography Newsletter 1980, 8(2):52-56

87. Instant coffee - Determination of free and total carbohydrate contents - Method using high-performance anionexchange chromatography. Standardization IOf. ISO II292 Geneva: ISO; 1995

88. Papini-Terzi FS, Rocha FR, Vencio RZ, Oliveira KC, Felix Jde M, Vicentini R, Rocha Cde S, Simoes AC, Ulian EC, di Mauro SM, et al:: Transcription profiling of signal transduction-related genes in sugarcane tissues. DNA Res 2005, I 2(I):27-38.

89. Murashige T, Skoog F: A revised medium for rapid growth and bioassys with tobacco tissue culture. Physiol Plant 1962, I 5:473-497.

90. Livak KJ, Schmittgen TD: Analysis of relative gene expression data using real-time quantitative PCR and the 2(-Delta Delta C(T)) Method. Methods 200I, 25(4):402-408

91. Iskandar HM, Simpson RS, Casu RE, Bonnett GD, MacLean DJ, Manners JM: Comparison of Reference Genes for Quantitative Real-Time Polymerase Chain Reaction Analysis of Gene Expression in Sugarcane. Plant Molecular Biology Reporter 2004, 22:325-337.

92. Altschul SF, Madden TL, Schäffer AA, Zhang J, Zhang Z, Miller W, Lipman D]: Gapped BLAST and PSI-BLAST: a new generation of protein database search programs. Nucleic Acids Res 1997 , 25(I7):3389-3402.

93. Thompson JD, Higgins DG, Gibson T]: CLUSTAL W: Improving the sensitivity of progressive multiple sequence alignment through sequence weighting, position-specific gap penalties and weight matrix choice. Nucleic Acids Res 1994, 22:4673-4680

94. Saitou N, Nei M: The neighbor-joining method: a new method for reconstructing phylogenetic trees. Mol Biol Evol 1987. 4(4):406-425

95. Tamura K, Dudley J, Nei M, Kumar S: MEGA4: Molecular Evolutionary Genetics Analysis (MEGA) software version 4.0. Mol Biol Evol 2007, 24(8): I596-I599. 